\title{
Industrial Applications of Enzymes: Recent Advances, Techniques, and Outlooks
}

\author{
Jordan Chapman, Ahmed E. Ismail * and Cerasela Zoica Dinu * \\ Department of Chemical and Biomedical Engineering, Benjamin M. Statler College of Engineering and Mineral \\ Resources, West Virginia University, P.O. Box 6102, Morgantown, WV 26506, USA; jschapman@mix.wvu.edu \\ * Correspondence: ahmed.ismail@mail.wvu.edu (A.E.I.); cerasela-zoica.dinu@mail.wvu.edu (C.Z.D); \\ Tel.: +1-304-293-9338 (C.Z.D); Fax: +1-304-293-4139(C.Z.D)
}

Received: 5 May 2018; Accepted: 30 May 2018; Published: 5 June 2018

\begin{abstract}
Enzymes as industrial biocatalysts offer numerous advantages over traditional chemical processes with respect to sustainability and process efficiency. Enzyme catalysis has been scaled up for commercial processes in the pharmaceutical, food and beverage industries, although further enhancements in stability and biocatalyst functionality are required for optimal biocatalytic processes in the energy sector for biofuel production and in natural gas conversion. The technical barriers associated with the implementation of immobilized enzymes suggest that a multidisciplinary approach is necessary for the development of immobilized biocatalysts applicable in such industrial-scale processes. Specifically, the overlap of technical expertise in enzyme immobilization, protein and process engineering will define the next generation of immobilized biocatalysts and the successful scale-up of their induced processes. This review discusses how biocatalysis has been successfully deployed, how enzyme immobilization can improve industrial processes, as well as focuses on the analysis tools critical for the multi-scale implementation of enzyme immobilization for increased product yield at maximum market profitability and minimum logistical burden on the environment and user.
\end{abstract}

Keywords: enzyme; immobilization; industrial applications; scale-up; techno-economic analysis; life cycle

\section{Introduction}

Enzymes are highly efficient biocatalysts researched for industrial-scale catalysis because of their several distinct advantages that range from their operation in milder reaction conditions, to their exceptional product selectivity, and to their lower environmental and physiological toxicity [1-4]. The above listed advantages were shown to translate into reduced operating costs when they were effectively employed as biocatalysts in chemical processes. As such, their lower energy requirements, mitigation of waste generation, and simplified production routes $[1,3,5]$ have been partially realized in the pharmaceutical, food, and beverage industries [6-12]. Further work remains however to demonstrate that biocatalysis is economically competitive in other industries, such as natural gas conversion and biofuel production [13-19]. Moreover, across the various industries where biocatalysis can be used, a recurring barrier persists, i.e., the application of enzyme catalysis in chemical processes is limited by the lack of enzyme stability at high temperatures or in turbulent flow regimes, as well as in potentially toxic solvents [20-27]. Thus, concentrated approaches spanning over various disciplines are focusing on the identification and production of robust, stable biocatalysts suitable for application in a broader range of industrial settings [1,3,20-29].

This review focuses on how enzyme catalysis has been advantageously used in chemical processes and which industries can further exploit enzyme catalysis for improved outcomes. 
Further, this review contains an in-depth discussion of the latest enzyme immobilization techniques, how enzyme immobilization can aid in the realization of fully optimized biocatalysts, and the combination of technical expertise that will drive the scale-up of these economically competitive immobilized-biocatalytic processes for industrial applications.

\section{Enzyme Implementation: A Societal Need}

The pharmaceutical, food and beverage, detergent, and biofuel industries have reaped the advantages of enzyme catalysis in commercial-scale applications, while other industries, such as natural gas conversion and fine chemical production, are only recently considering their use [1-4]. In industrial-scale chemical production, the benefits of biocatalysis are often multifaceted, and as such, enzymes are attractive catalysts owing to mild reaction conditions, high product selectivity, and low environmental impact, and thus have been employed for both simplified chemical synthesis routes and improved chemical process economics $[1,3,5]$; Table 1 illustrates the broad applications of enzyme catalysis throughout various industries.

Table 1. Industrial applications of enzyme catalysis.

\begin{tabular}{|c|c|c|c|}
\hline Sector & Enzymes & Applications & References \\
\hline Pharmaceuticals & $\begin{array}{l}\text { Nitrile hydratase, transaminase, } \\
\text { monoamine oxidase, lipase, } \\
\text { penicillin acylase }\end{array}$ & $\begin{array}{l}\text { Synthesis of intermediates for production } \\
\text { of active pharmaceutical ingredients }\end{array}$ & {$[2,4,30-38]$} \\
\hline Food Processing & $\begin{array}{l}\text { Trypsin, amylase, glucose } \\
\text { isomerase, papain, pectinase }\end{array}$ & $\begin{array}{l}\text { Conversion of starch to glucose, production } \\
\text { of high fructose corn syrup, production of } \\
\text { prebiotics, debittering of fruit juice }\end{array}$ & {$[2,5,9-12,39-43]$} \\
\hline Detergent & Protease, lipase, amylase, cellulase & $\begin{array}{l}\text { Stain removal, removal of fats and oils, } \\
\text { color retention, }\end{array}$ & [44-48] \\
\hline Biofuels & Lipase, cellulase, xylanase & $\begin{array}{l}\text { Production of fatty acid methyl esters, } \\
\text { decomposition of lignocellulotic material } \\
\text { for bioethanol production }\end{array}$ & {$[18,19,44,49-57]$} \\
\hline Paper and Pulp & Lipase, cellulase, xylanase & $\begin{array}{l}\text { Removal of lignin for improved bleaching, } \\
\text { improvement in fiber properties }\end{array}$ & {$[2,4,44,58-61]$} \\
\hline
\end{tabular}

Though the advantages of biocatalysis are numerous, commercial enzyme catalysis is used only if it affords a process improved economics of operation [5]. According to Business Communication Company (BCC) Research, the global enzyme market is projected to grow from $\$ 5.01$ billion in 2016 to $\$ 6.32$ billion in 2021 (Figure 1), with market trends predicting a shift toward increased technical enzyme production including those used in textile, paper, leather, and biodiesel industries where excess waste generation incurs fines from environmental agencies [44]. Such market projections were shown to be largely driven by process development in enzymatic biofuel production, which present good opportunities for the scale-up of immobilized biocatalysts [44,49]. 


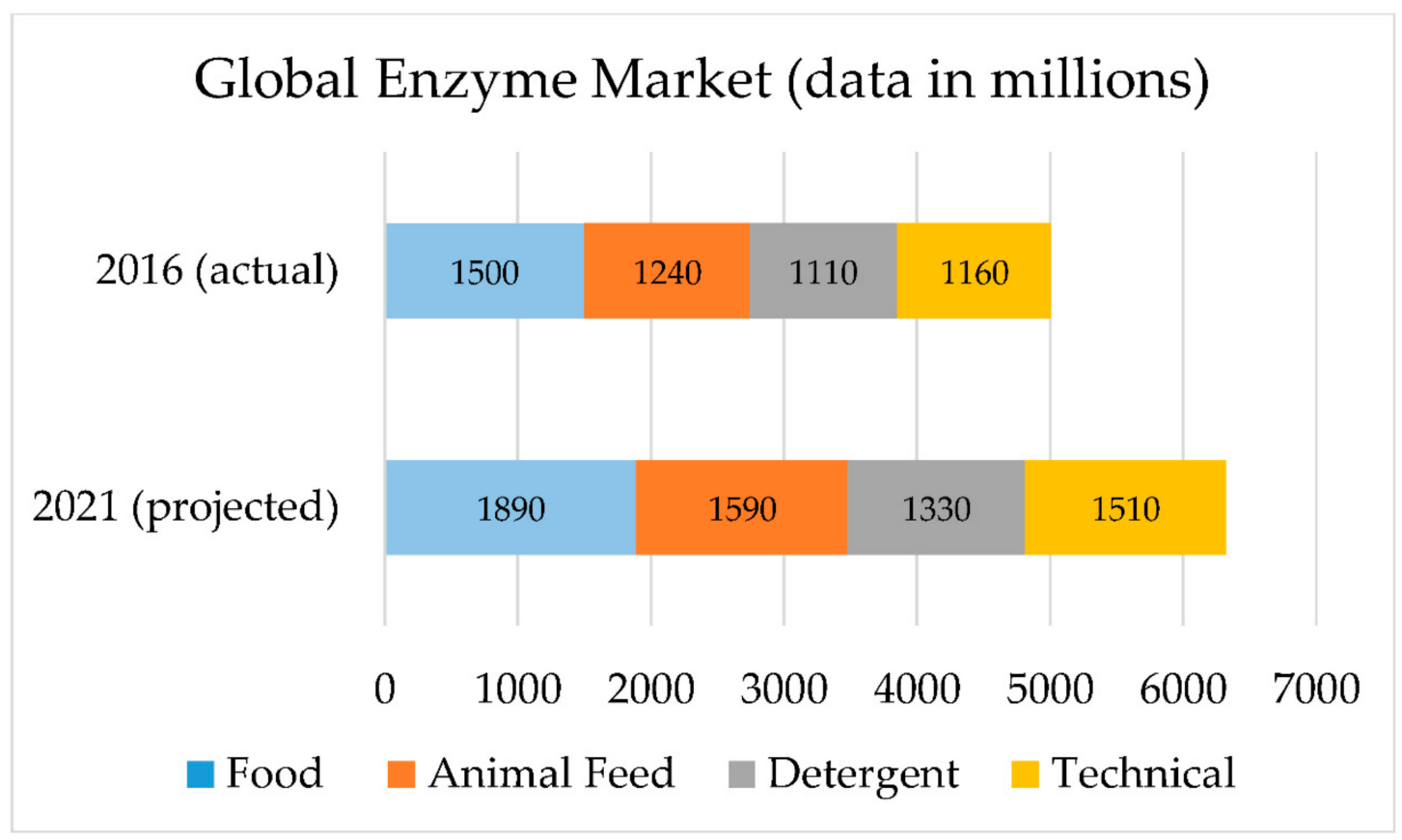

Figure 1. Global enzyme market in 2016 (top) and projected global enzyme market in 2021 (bottom). Figure adapted from data included in Ref. [44].

\section{Enzyme Immobilization for Expanded Scope of Implementation}

Studies in enzyme immobilization, i.e., the attachment of the biocatalyst to a material with desired physical, chemical, electrical, or mechanical properties, have shown that immobilizing biocatalysts can improve their activity and stability across a broader range of operating conditions, with the additional functionality being imparted depending upon both the method of immobilization as well as the inherent properties of the materials used in such immobilization [49,62-66]. It was further demonstrated that the immobilized biocatalysts are novel in that their application simultaneously also allows for a reduced number of processing steps due to the facile separation of the biocatalyst itself from its reaction mixture, their retention of catalytic activity, and the resulting appreciable degree of reusability [5,20-27]. Table 2 lists both the common advantages and disadvantages associated with the use of an immobilized biocatalyst, as highlighted in previous research.

Table 2. Advantages and disadvantages of enzyme immobilization.

\begin{tabular}{ll}
\hline \multicolumn{1}{c}{ Advantages } & \multicolumn{1}{c}{ Disadvantages } \\
\hline Functionality for use in continuous processes & Loss of enzyme activity \\
\hline $\begin{array}{l}\text { Improved stability in broader range of operating } \\
\text { conditions (e.g., pH, temperature etc.) }\end{array}$ & $\begin{array}{l}\text { Immobilization of enzyme in undesired conformation and } \\
\text { subsequent loss of activity }\end{array}$ \\
\hline Facile separation of enzyme from product & $\begin{array}{l}\text { Cost of carrier and additional preparation materials and } \\
\text { methods, as well as laborious training strategies }\end{array}$ \\
\hline Reusability of enzyme & Mass transfer limitations \\
\hline $\begin{array}{l}\text { Immobilization in preferred conformation and at } \\
\text { preferred location }\end{array}$ & Laborious and time-consuming immobilization processes \\
\hline
\end{tabular}

Determining the appropriateness of implementing immobilized biocatalysis on an industrial scale requires a critical evaluation of both technical and economic factors as well as of the process in consideration. Often, the benefits of immobilization must be multiple-fold to see an improvement over the economics of free enzyme-catalyzed processes [5]. As such, efficient enzyme immobilization depends critically on 
techniques that afford high degrees of stability and reusability, as well as additional functionality without significant hindrances to enzyme activity and product selectivity [49,62-66].

Three main immobilization techniques (Figure 2) have been largely reported in the literature, namely carrier-bound attachment, encapsulation or entrapment, and the formation of crosslinked enzyme aggregates [20-27]. Two kinetic parameters are often calculated for an immobilized enzyme to assess the effects of immobilization on the enzyme's catalytic efficiency when compared to the non-immobilized enzyme counterpart, i.e., the Michaelis constant $K_{m}$ and maximal reaction velocity $V_{\max } . K_{m}$ compares the rates of substrate-enzyme binding and dissociation with smaller values of $K_{m}$ suggesting that binding dominates and indicating higher enzyme-substrate affinity [1]. $V_{\text {max }}$ measures the rate at which an enzyme converts the substrate to product, and when controlled for catalytic mass, the value of $V_{\max }$ is an appropriate measure of catalytic activity [1].

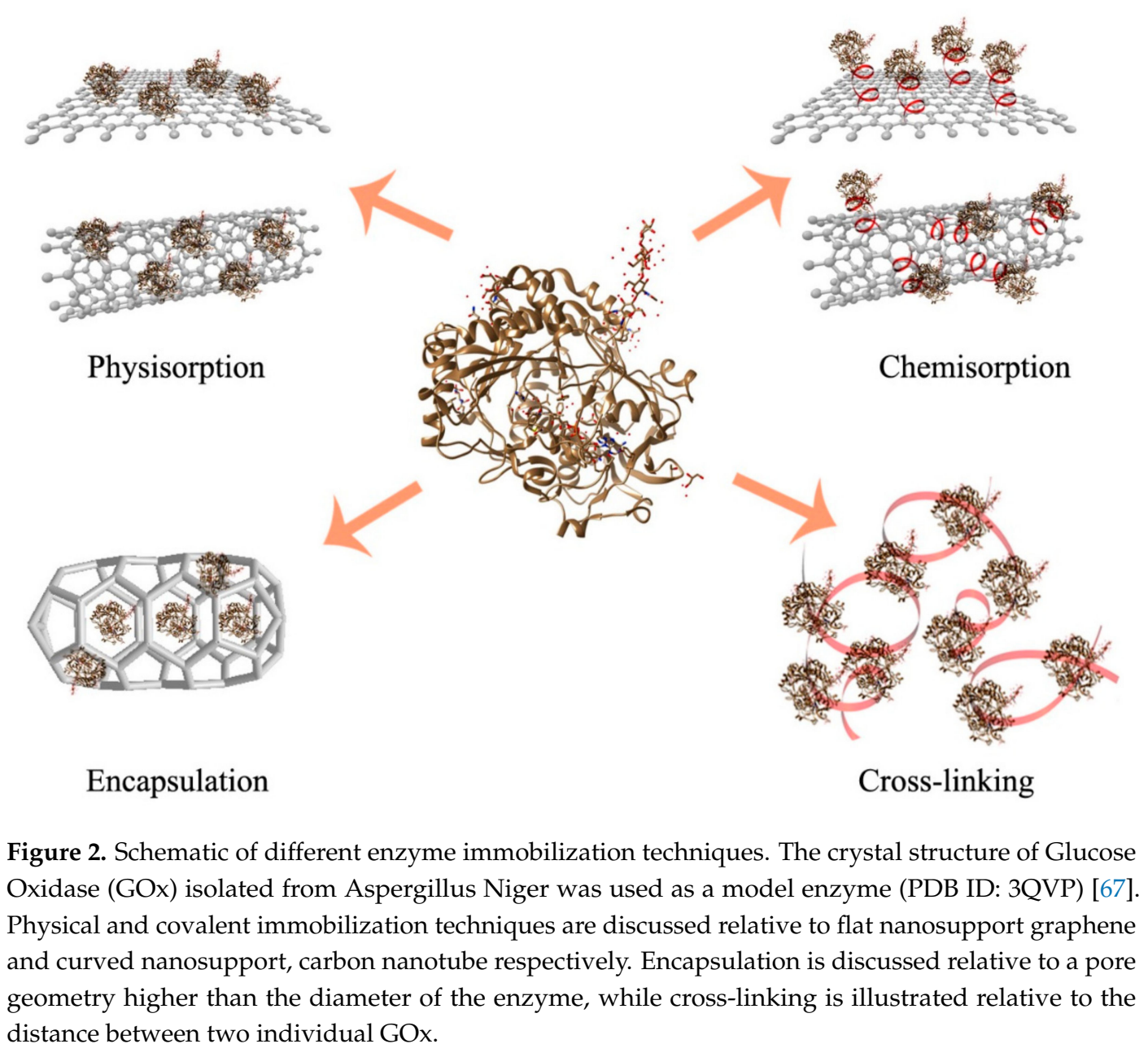

\subsection{Carrier-Bound Enzyme Immobilization through Both Physical and Chemical Binding}

Carrier-bound enzyme immobilization is characterized by the attachment of the biocatalyst onto a prefabricated solid material with the appropriate immobilization methods being selected to allow for optimization of the catalytic performance $[5,68]$. The two common methods of carrier-bound enzyme immobilization are physisorption and chemisorption, with physical adsorption offering the benefit of a generally universal, facile immobilization method, since the binding mechanism is not dependent on a site-specific chemical reaction between the enzyme and the support [49], while the covalent bonding requires site-specific chemical interactions between the enzyme and the support or the use of a cross-linking reagent [17]. 
Even though a wide range of both organic and inorganic supports, including ceramics and metal oxides [69,70], nanomaterials [68,71-75], and polymers [76-84] have been investigated as supports for enzyme immobilization [24], the application of such physically adsorbed enzyme-support conjugates is limited by enzyme leaching as well as a decrease in the enzyme's catalytic efficiency [24]. Falus et al., for instance, reported the immobilization of subtilisin A onto various silica gels for the continuous production of racemic N-Boc-phenylalanine ethyl thioester, an important pharmaceutical intermediate [83]. Subtilisin A was physisorbed to surface-grafted silica gel and used as packing in three reactors in series for the dynamic kinetic resolution of racemic N-Boc-phenylalanine ethyl thioester. At optimal conditions, the continuous flow process yielded a $97 \%$ conversion of the substrate at an enantiomeric excess of $99.5 \%$, with the immobilized subtilisin A retaining catalytic activity after $120 \mathrm{~h}$ in continuous flow operation. The improved activity retention and shelf life was reported to be up to 1 year and was attributed to the increased thermostability of the enzyme upon physisorption [83].

Burkholderia sp. lipase, an enzyme widely studied for the production of biodiesel, was immobilized onto magnetic nanoparticles and evaluated for its catalytic activity. Tran et al. found that methyl-grafted $\mathrm{Fe}_{3} \mathrm{O}_{4}-\mathrm{SiO}_{2}$ nanocomposites had a high affinity for lipase (29.5 mg lipase $\mathrm{g}^{-1}$ nanocomposite being adsorbed) most likely due to the porous structure of the silica coating. A higher $K_{m}$ value and lower $V_{\max }$ value were however reported for the immobilized enzyme, thus indicating that the immobilization process decreased both the catalytic activity and its efficiency, likely due to the non-specific attachment and deformation of the enzyme active site and its increased mass transfer resistance. The immobilization also allowed for the improved reusability and separation of lipase in the transesterification of olive oil with methanol to produce fatty acid methyl esters (FAMEs). Physisorption of lipase onto magnetic methyl-grafted $\mathrm{Fe}_{3} \mathrm{O}_{4}-\mathrm{SiO}_{2}$ nanoparticles was shown to retain significant activity for up to 10 reaction cycles owing to its increased stability from multi-point hydrophobic interactions with grafted methyl groups [70].

Zhang et al. reported on the immobilization of catalase onto carbon nanotubes for application in nanoelectronics, biosensing, and high-resolution imaging. Carbon nanotubes have been extensively studied as supports for enzymes due to their high surface area-to-volume ratio and biocompatibility [72]. An optimal enzyme loading $\left(1.88 \mathrm{mg} \mathrm{m}^{-2}\right)$ was found for the physisorption of catalase onto oxidized single wall nanotubes (O-SWNT). A $K_{m}$ value for O-SWNT-catalase conjugates, relative to that of the free enzyme, was reported to be $27.0 \%$, indicating that the adsorptive interactions induced conformational changes in the secondary structure of the enzyme, as confirmed by Fourier transformation infrared spectroscopy and circular dichroism (CD) analyses. $V_{\max }$ for O-SWNT-catalase conjugates was reported to be 6.3 times lower than that of free enzyme. An analysis of CD spectra for immobilized catalase suggested that hydrogen bonding between enzyme and O-SWNT caused increased enzyme rigidity and therefore increased activity retention [72]. Lastly, Nidetzky's group has shown that chimeras of target enzymes can be combined with silica binding modules (SBM) through noncovalent interaction and become very tightly attached to such underivatized glass, even at physiological $\mathrm{pH}$ conditions. Moreover, the research has shown that the immobilized enzymes displayed full biological activity, suggesting that their binding to such a glass surface could be controlled through their specific orientation at the SBM interface $[85,86]$.

Immobilization via covalent attachment was shown to offer strong chemical bonding that prevents significant enzyme leaching and further mitigates the loss of enzyme active sites [1]. Covalent binding methods are however more intensive and chemically harsher than physical adsorption, often requiring activation steps capable of inducing enzyme denaturation [87]. Further, the selection of an enzyme to be covalently immobilized must be carefully evaluated to ensure optimal catalytic efficiency, and as such, the enzyme-support covalent bond, for instance, should not affect the amino acids associated with the enzyme active site, or the immobilization method may cause loss of catalytic activity [87].

Zhu and Sun successfully immobilized lipase from Candida rugosa onto poly(vinyl alcohol-co-ethylene) (PVA-co-PE) nanofibrous membranes via glutaraldehyde activation for hydrolysis of p-nitrophenyl palmitate [75]. It was determined that covalent bonding caused an increase in $K_{m}$ and 
a decrease in $V_{\max }$ due to slower substrate diffusion and decreased enzyme mobility at the interface. Immobilized lipase was also found to retain nearly $90 \%$ of its activity after incubation in a phosphate buffer system at $55{ }^{\circ} \mathrm{C}$ for $75 \mathrm{~min}$, while free enzymes were found to retain only approximately $20 \%$ of their initial activity. Significantly more activity than free lipase was also retained after 30 days of storage at $4{ }^{\circ} \mathrm{C}$ most likely due to a decrease in denaturation [75].

Kuo et al. reported on the immobilization of the same enzyme for the synthesis of 2-phenylethyl acetate, the major aromatic ester of rose fragrance. In this study, lipase was covalently bonded to polyvinylidene fluoride (PVDF) membrane, activated via 1,4-diaminobutane and glutaraldehyde,

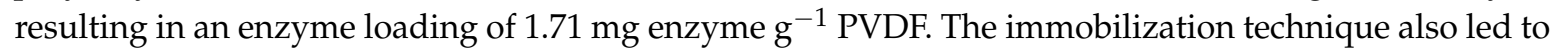
improved catalytic activity with only slightly hindered catalytic efficiency in n-hexane, likely due to the preservation of the tertiary structure in the organic medium resulting from covalent immobilization [77]. Complementarily, a study by Mendes et al. demonstrated that the optimal immobilization protocol among carrier-binding methods for lipase from Penicillium camembertii is covalent attachment to an epoxy-silica-polyvinyl alcohol composite. The covalently bound lipase was found to have a lower, less variable enzyme loading capacity than the physically adsorbed lipase. Moreover, the optimal case for covalently bound lipase yielded a hydrolytic activity nearly double that of physical adsorption as well as a greater activity retention. Covalent attachment of lipase to epoxy-silica-polyvinyl alcohol also resulted in improved thermostability compared to that of free lipase [88].

Epoxide hydrolase (EH) has also been studied for its potential application in the synthesis of high-value, enantiomerically pure pharmaceutical intermediates and other bioactive molecules. Petri et al., for instance, proposed the covalent attachment of EH from Aspergillus niger to epoxide-activated silica gel for the enantioselective hydrolysis of p-nitrostyrene oxide. Immobilization onto the silica gel resulted in a relatively high immobilization yield of nearly $70 \%$, and the immobilized $\mathrm{EH}$ was found to retain about $90 \%$ of its activity relative to free $\mathrm{EH}$, as well as good storage stability over the span of few months. The covalent immobilization of EH caused no decrease in the enantiomeric selectivity of p-nitrostyrene oxide hydrolysis and markedly improved the stability of EH in organic solvent of $20 \%$ DMSO [89].

Nanomaterials have been studied as supports for biocatalysts due to minimal mass transport limitations and high specific surface area for volume-efficient catalysis [22,68]. Li et al., for instance, used an electrospun polyacrylonitrile-glycopolymer nanofibrous membrane as a support for covalent binding of catalase from bovine liver. Immobilized catalase activity was about $50 \%$ of that of the free catalase, but was found to be stable across broader ranges of temperatures and pHs. It was also found that covalently immobilized catalase retained approximately $80 \%$ relative activity after storage at $4{ }^{\circ} \mathrm{C}$ for 30 days, whereas free catalase retained no relative activity when in the same conditions [68]. Alptekin et al. optimized a protocol of the chemical attachment of catalase onto Eupergit $C$, a macroporous derivative of methacrylamide reported to be chemically and mechanically stable as a catalyst for operation in batch and plug flow reactors. The ratio of $K_{\text {cat }}$ to $K_{m}$ was calculated to assess the catalytic efficiency of free and immobilized catalase and was found to be nearly 2 orders of magnitude, thus suggesting that the immobilized enzyme was less efficient in converting the substrate to product. However, immobilization was shown to improve enzyme shelf life and operational stability as a biocatalyst in batch and plug flow reactors. Studies showed that immobilized catalase retained nearly $78 \%$ of initial activity when measured 28 days after immobilization, whereas free catalase was inactive after only 11 days of storage. Furthermore, immobilized catalase retained $50 \%$ activity at $82 \mathrm{~min}$ in a plug flow reactor [90].

\subsection{Enzyme Entrapment}

Enzyme entrapment is the immobilization of a biocatalyst into carriers of varying degrees of porosity and permeability [27]. Enzymes immobilized via entrapment exhibit improved stability due to intensified control of their microenvironment and were also shown to be more catalytically active at higher temperatures in organic solvents, as well as easily separated from substrate-product reaction mixture [87]. 
Immobilization via entrapment in a variety of carriers, e.g., sol gels, hydrogels, polymers, nanomaterials, has been researched for the employment of biocatalysts in the synthesis of organic compounds and for novel biosensing systems $[64,66]$. Complementarily, the immobilization of lipase has been proposed for application in the production of flavor and fragrance chemicals, as well. Ferraz et al., for instance, investigated the viability of geranyl propionate synthesis using lipase from Penicillium crustosum as biocatalyst. Lipase was entrapped in beads nearly $0.5 \mathrm{~cm}$ in diameter via a crosslinking reaction between calcium chloride and sodium alginate. Calcium-alginate beads containing lipase were optimized further for geraniol and propionate conversion, as well as tested for reusability. Results show that the activity retention of immobilized lipase decreased linearly with respect to the number of cycles of use, suggesting that activity loss was due to enzyme leaching during each cycle [91]. Risso et al. studied the same entrapment method for the immobilization of inulinase from Kluyveromyces marxianus, an important biocatalyst in the production of high fructose syrups. Inulinase, entrapped in calcium-alginate beads, was characterized by the determination of its kinetic parameters, as well as its thermostability and $\mathrm{pH}$ stability in varying degrees of organic solvents. The $K_{m}$ value of immobilized inulinase was found to be significantly less than that of free inulinase at optimal mass fractions of organic solvent, while the $V_{\max }$ value of immobilized inulinase was comparable to that of free inulinase in the same conditions. However, mass transfer resistances, which would likely be the rate-limiting process, were not considered in the kinetic analysis of the immobilized biocatalyst [92].

Arica et al. proposed the entrapment of catalase from bovine liver in thermally reversible cylinders of poly(isopropylacrylamide-co-hydroxyethylmethacrylate) for reactor system applications. Immobilized catalase exhibited a decrease in catalytic activity and enzyme-substrate affinity, and retained less activity at higher temperatures than free catalase. It was also found that an increase in temperature caused for a decrease in hydrogel swelling and higher mass transfer resistance. The apparent kinetic parameters of the immobilized catalase were largely attributed to the temperature-dependent behavior of the hydrogel carrier itself. The entrapment technique allowed for enzyme reusability and increased storage stability. Immobilized catalase also showed $78 \%$ activity retention after storage at $4{ }^{\circ} \mathrm{C}$ for 20 days, while free catalase retained none of its activity in the same storage conditions. Furthermore, hydrogel-entrapped catalase was found to retain approximately $95 \%$ activity for 6 cycles in the batch reactor system [93].

Singh et al. studied the apparent kinetic and stabilizing effects of the encapsulation of bovine liver catalase in hollow silica nanoparticles (HSNPs). No absorption peaks were observed for catalase or hydrogen peroxide in the supernatant liquid isolated from the immobilization procedure, thus indicating an immobilization yield of nearly $100 \%$. It was further determined that the encapsulation technique decreased both enzyme's activity and enzyme-substrate affinity. However, immobilized catalase showed significantly improved stability throughout a broad range of $\mathrm{pHs}$ and temperature conditions. Free catalase was completely denatured when tested for activity at $70^{\circ} \mathrm{C}$, while encapsulated catalase was found to have optimal catalytic activity at $80^{\circ} \mathrm{C}$. The encapsulation of catalase within HSNPs-rather than the physical adsorption of catalase onto HSNPs—-was demonstrated by the thermostability results for immobilized enzyme. It is expected that physically adsorbed enzyme would show a loss of catalytic activity near the denaturation temperature of free enzyme [94].

Yan et al. reported the successful nanogel encapsulation of bovine carbonic anhydrase (BCA), a metalloenzyme that is studied for applications in carbon capture and biocatalytic enrichment of natural gas where industrial application is limited by the almost total loss of enzyme catalytic activity at $63{ }^{\circ} \mathrm{C}$ due to the irreversible aggregation of BCA. Acryloylation and subsequent in-situ polymerization of BCA to form single BCA nanogels were performed, thus imparting molecular structural stability to the enzyme while mitigating mass transfer limitations. BCA nanogels exhibited similar catalytic activity as free BCA and showed significant retention of activity at temperatures greater than $63^{\circ} \mathrm{C}$. It was also determined that nanogel encapsulation preserved the secondary structure of $\mathrm{BCA}$, therefore inhibiting irreversible aggregation and allowing for catalytic activity even at $81^{\circ} \mathrm{C}$ [95]. 
Enzyme entrapment in biocompatible nanoparticles and solid supports has also been reported as a novel approach for the improvement of enzyme activity as a result of biocatalyst-carrier interactions. Studies of enzyme entrapment in solid carriers have shown that for optimal immobilization conditions it is possible to "lock" immobilized enzymes into more catalytically active conformations [96]. Prakasham et al., for instance, investigated the kinetic parameters and stability of amylase entrapped in matrices comprised of nickel-impregnated silica paramagnetic particles. It was observed that the entrapped amylase had more rapid starch hydrolysis than the free amylase, for all the tested $\mathrm{pHs}$ and temperature conditions. A lower $K_{m}$ value was however recorded for the immobilized amylase, most probably indicating that the entrapment technique yielded a more efficient, robust biocatalyst [96].

$\mathrm{Wu}$ et al. reported on the facile co-immobilization of enzymes glucose oxidase (GOx) and horseradish peroxidase (HRP) into a metal-organic framework. The entrapment was performed by mixing solutions of zinc nitrate, GOx, and HRP, and 2-methylimidazole at ambient conditions for $0.5 \mathrm{~h}$ resulted in the enzyme-embedded zeolitic imidazolate framework (GOx\&HRP/ZIF-8). The catalytic activity of such conjugate was compared to that of a mixture of GOx/ZIF-8 and HRP/ZIF-8 to determine any changes in efficiency as resulted from the co-immobilization technique. Analysis showed that GOx\&HRP/ZIF-8 exhibited a 2 times higher activity than the mixture of single-immobilized conjugates due to a significant decrease in mass transfer resistance. Furthermore, GOx\&HRP/ZIF-8 were found to retain significantly more activity than free enzyme in organic solvent and when stored at room temperature [97]. Currently however, the successful scale-up of entrapped enzymes for biocatalysis is prevented by mass transfer limitations of substrate through carrier material, enzyme leaching, and low total catalytic mass of enzyme-carrier conjugate [24]. Lastly, Lin et al. reported on the entrapment of HRP in inorganic interfaces made with cooper phosphate supports and in aqueous solution. Results showed that the hierarchical flower-like spherical structures considerably enhanced enzyme's activity relative to that of the free enzyme in solution. In addition, the hybrid interfaces also exhibited excellent reusability and reproducibility even when several cycles for evaluating the active hydrogen peroxide $\left(\mathrm{H}_{2} \mathrm{O}_{2}\right)$ release were performed [98].

\subsection{Cross-Linked Enzyme Aggregates}

Enzyme immobilization via the formation of cross-linked enzyme aggregates (CLEAs), one of the newest class of immobilization techniques, has also been researched considerably since its development [99] for application in industrial biotransformations of fine chemicals and pharmaceuticals [24]. The general preparation of CLEAs is carried out via the aggregation of given soluble enzymes when using a precipitating reagent, such as ammonium sulfate [100-102], acetone [103], ethanol [102], or tert-butanol [100], followed by the subsequent copolymerization of enzyme aggregates with a cross-linking agent, most frequently glutaraldehyde [62,99-109]. However, analysis showed that aggregate cross-linking is not a universal immobilization method and should thus be optimized for each target biocatalyst, with the precipitating and cross-linking agents having to be selected carefully to ensure that immobilization does not adversely affect enzyme activity $[62,100-103,105]$.

CLEAs were shown to offer the benefits of enhanced shelf life and operational stability, reusability, and exceptional resistance to the leaching of immobilized biocatalyst in aqueous media, while not suffering from substrate diffusion limitations that could potentially reduce catalytic activity [100]. In certain instances, CLEAs were shown to possess higher catalytic activities than the corresponding free enzymes, and this phenomenon, known as hyperactivation, was attributed to the aggregation of enzyme in a pre-organized tertiary structure that rendered it permanently insoluble upon cross-linking [24]. Thus, CLEAs showed a large potential for application in industrial-scale processes owing to high catalytic productivity and inexpensive immobilization methods [24]. However, the successful scale-up of applications were dependent on improving CLEA's mechanical properties while better defining separation criteria for continuous processes [24]. 
Specifically, Lai et al. reported the direct formation (from fermentation broth) and stability analysis of CLEAs with lipase from Penicillium expansum (PEL) in various solvents, for the production of biodiesel from corn and microalgal oil, respectively. In this study, PEL-CLEAs were found to be less catalytically active than free PEL, likely due to mass transfer limitations of the large substrate molecules. PEL-CLEAs also showed an improved stability over free PEL at increased temperatures and in various conditions of $\mathrm{pH}$. The clumping of PEL-CLEAs and loss of enzyme active sites was however determined to cause a decrease in the yield of biodiesel. PEL-CLEAs also exhibited substantial activity retention in nonaqueous solutions, suggesting that the immobilization method can be geared toward industrial production of biodiesel [106].

Nguyen and Yang produced combined cross-linked enzyme aggregates (combi-CLEAs) of GOx and HRP for the catalysis of a cascade chemical reaction applicable to glucose detection biosystems [105] and pharmaceutical wastewater treatment [109]. The combi-CLEAs were optimized for the cross-linking density and mass ratio of GOx to HRP for ensuring maximal catalytic activity and enzyme stability. Upon optimization, combi-CLEAs showed similar catalytic activity relative to free enzymes, but lower values of $K_{m}$ were most likely a result of two factors: the distance of mass transfer for hydrogen peroxide intermediate, which was substantially reduced by the co-immobilization technique; and the cross-linking of GOx, resulting in decreased inhibition in the presence of $\mathrm{H}_{2} \mathrm{O}_{2}$ [105].

Vafiadi et al. reported similarly promising results for the use of combi-CLEAs on three commercial enzyme mixtures exhibiting feruloyl esterase activity. The authors reported on the immobilization via aggregate cross-linking and assessed its kinetic activity relative to free enzyme in ternary mixtures of n-hexane, 1-butanol, and water. Combi-CLEAs were designed to retain maximal catalytic activity by the evaluation of 10 aggregating agents, while the efficiency was optimized by varying the concentration of the cross-linking agent. A product yield of $97 \%$ was reported upon the enzyme's precipitation via ammonium sulfate and cross-linking at a glutaraldehyde concentration of $100 \mathrm{mM}$. The use of ammonium sulfate with this precipitating agent was found to be advantageous because its solvation is an endothermic reaction. Notably, the activity of enzyme aggregates prior to cross-linking were found to be higher than that of the free enzyme, supporting evidence that suggests suitable immobilization techniques can lock enzymes in highly active conformations. Furthermore, combi-CLEAs were easily separated from the reaction mixture containing unreacted methyl ferulic esters, synthesized 1-butyl ferulate by centrifugation and later reused for furuloyl esterase activity, though the immobilized enzymes showed poor activity retention and stability [102].

Martins et al. formed magnetic cross-linked enzyme aggregates (mCLEAs) from rhamnopyranosidase (Rhmnase), a hydrolytic enzyme applicable in the production of valuable pharmaceutical compounds such as lipoprotein associated phospholipase A2 inhibitors, which are administered in the treatment of atherosclerosis [110]. Such magnetic aggregates were evaluated for their catalytic activity with different cross-linking and precipitating agents and subsequently compared to CLEAs@Rhmnase for reusability in a batch reactor system. CLEAs@Rhmnase were found to retain nearly $100 \%$ activity after 5 reutilization cycles of $24 \mathrm{~h}$ each, however, the CLEAs@Rhmnase showed a significant loss in activity after 7 reutilization cycles. Conversely, mCLEAs@Rhmnase showed an initial loss in activity of approximately $40 \%$ after one reutilization cycle and near constant activity thereafter, likely due to the higher physical stability of the magnetic aggregates. Additionally, mCLEAs@Rhmnase were shown to be more catalytically active and efficient than CLEAs@Rhmnase, suggesting that the selection of immobilization materials should be critically assessed for ensuring high biocatalytic turnover. It was determined that magnetic enzyme aggregates are more suitable biocatalysts for a scaled up process owing to improved reusability and stability [104].

Zhao et al. reported the use of CLEAs of Pseudomonas sp. lipase (CLEA-PSL) as a biocatalyst for the enantioselective resolution of (S)-N-(2-ethyl-6-methylphenyl) alanine, a chemical precursor in the production of widely used herbicides [111]. Precipitation and cross-linking conditions were optimized for the formation of CLEA-PSL, and kinetic parameters were determined for free and immobilized lipase, respectively. CLEA-PSL were found to be more active than the free lipase, and it was also 
noted that $48 \mathrm{~h}$ were required for free lipase to reach a substrate conversion of $50 \%$, while only $12 \mathrm{~h}$ were needed for the immobilized lipase to achieve the same conversion and enantiomeric excess. The time difference was presumably due to an induced change to a more catalytically active enzyme conformation upon immobilization. The evaluation of kinetic parameters determined that CLEA-PSL also showed an improved affinity for substrate, most likely due to the changes in the enzyme's secondary structure caused by immobilization. Lastly, the immobilized lipase was found to be more thermostable than the free lipase and retained nearly $80 \%$ of its initial activity after ten reutilization cycles in a batch reactor and with no reported loss of enantioselectivity [103].

Enzyme aggregate cross-linking has also been proposed as a method to improve biocatalysts that are currently employed on an industrial scale. Illanes et al., for instance, implemented CLEAs from recombinant penicillin acylase for the production of cephalexin with increased enzyme stability and global productivity ( $\mathrm{g}$ cephalexin $\mathrm{g}^{-1}$ biocatalyst). Free penicillin acylase was found to require a lesser reaction time, but CLEAs were advantageous for preservation of enzyme activity. Free enzyme retained 50\% residual activity after $30 \mathrm{~h}$, while CLEAs retained an equal amount of activity after $78 \mathrm{~h}$. Furthermore, CLEAs were found to have an increased total specific productivity ( $135.5 \mathrm{~g}$ cephalexin $\mathrm{g}^{-1}$ biocatalyst) than that of free penicillin amylase (of only $40.1 \mathrm{~g}$ cephalexin $\mathrm{g}^{-1}$ biocatalyst) with such an increase in the reusability, justifying a slight loss of catalytic activity due to an overall increase in the production potential of cephalexin [101].

Lastly, the intramolecular cross-linking of non-aggregated enzymes has been investigated as a method of inducing increased rigidity to and preventing non-specific protein-protein associations of multimeric enzymes, thus preserving catalytic activity when coupled with another immobilization method [112-114]. Dinu et al. demonstrated that cross-linking of perhydrolase S54V (AcT), i.e., an enzyme that catalyzes the perhydrolysis of propylene glycol diacetate to decontaminant agent peracetic acid, allowed for the novel integration of nanobiocatalytic conjugates with latex-based paint that led to the formation of a bioactive decontaminating composite. The study also found that AcT, cross-linked with polyfunctional aldehyde dextran, retained a greater degree of catalytic activity when covalently bound to single walled carbon nanotubes (SWNTs) as compared to covalent bonding of AcT to SWNTs. The superior activity retention of AcT was attributed to cross-linking with aldehyde dextran that conferred increased rigidity to the enzyme and led to the preservation of its secondary structure upon covalent immobilization onto SWNTs [112].

\section{Intensified Approach for Designing Improved Biocatalysts}

The combination of different technical expertizes has allowed for the improved design of immobilized biocatalytic processes, but profitability seems to remain the determining factor for further enzyme-induced process development and implementation $[5,115,116]$. For instance, significant progress was made in protein design via directed evolutionary approaches, with such progress allowing for improved activity, stability, and substrate affinity, as well as reduced costs to isolate enzymes $[1,3,23,28,29]$. Directed evolution requires the administration of random mutations to the amino acids constituting an enzyme, which could be employed through chemical mutagenesis or DNA shuffling, followed by screening for the desired phenotype and the isolation of genes coding for any identified improved genetic variant [3]. As a result of such an advance, research teams have been successful not only in developing biocatalysts that may be deployed at high temperatures and extreme $\mathrm{pH}$ conditions, but also biocatalysts that have catalytic activities of several orders of magnitudes greater than those of naturally occurring ones [1,3,29]. For instance, researchers at Codexis and Merck successfully used such multiple iterations to increase enzyme-substrate affinity and to design an economically competitive enzyme-catalyzed process for subtilisin, a pharmaceutical used for diabetes treatment [2]. However, while progress in protein engineering has helped drive increased applications in industrial enzyme catalysis, it has not addressed all limitations, like the poor mechanical stability and limited reusability of the biocatalysts, the costs associated with their in vitro production, or further adoption in commercial-scale processes [5,20-27]. 
Molecular dynamics simulations (MDS) provide atomic level understanding of phenomena that determine the physical and catalytic characteristics of an immobilized biocatalyst [117-121]. Studies of molecular dynamics simulations, which carry out numerical integration of Newton's laws of motion at an atomistic scale, have been used to predict the structures and catalytic properties of enzymes at the molecular level, which have been extended to research in enzyme immobilization where accurate characterization of enzyme-carrier interactions provides insight into binding mechanisms [117-120]. An understanding of atomistic-level interactions has led to the development of efficient and optimized biodevices. For instance, Franca et al. were able to determine through MDS that the active site of acetyl co-enzyme A carboxylase (ACC) had a positive surface potential. This insight into ACC was used to devise an optimal electrostatic adsorption of ACC onto an AFM tip for improved biodevice functionality [119].

Basso et al. performed molecular simulations on endo- and exoinulinase to explain differences in regioselectivity between the two structures. Analyses of the three-dimensional structures were subsequently used to formulate an optimal immobilized biocatalyst that showed hyperactivity when compared to its native structure [118]. Qu et al. employed molecular simulations of a hydrolase MfphA adsorbed onto single walled carbon nanotubes (SWNTs) for verification of and insight into analytical results. Molecular modeling results illustrated preferred binding of two particular amino acids Trp201 and Met81 to carbon nanotubes, thus resulting in a loss of hydrolase activity due to blocking of the active site [117]. Studies using molecular simulations have illustrated the utility of computational modeling in optimization of immobilization techniques to reduce lab material costs and create insight into molecular phenomena for the development of optimal immobilized biocatalysts [117-120].

These analyses show that the adoption of critical evaluation criteria for immobilized enzyme processes on multiple scales-including molecular-level modeling and analysis, life cycle assessments, and techno-economic analyses-is paramount for economical scale-up [5,44,50-52,117-120]. Ultimately, the appropriateness of immobilized biocatalyst for industrial processes boils down to the fruition of additional profitability with the immobilized form of an enzyme often having to hold multiple benefits over free enzyme for process economics that could overcome the additional costs and constraints associated with the immobilization to a reduced loss of catalytic activity, while balancing the cost used for covering the possible materials to be used as supports $[5,116]$.

\section{Glucose Isomerase: A Model for Enzyme Immobilization}

The immobilization of glucose isomerase (GI) is considered an excellent model for commercial application of an immobilized enzyme where GI efficiently catalyzes the conversion of d-glucose to d-fructose in the production of high-fructose syrup (HFCS) [122]. The enzymatic production of HFCS was previously determined to be more economically competitive than conventional chemical methods requiring alkaline catalysis due to improved product quality, simplified production route, and reduction of undesired byproducts such as mannose and psicose [122].

Much research has been done on immobilization of GI since its development and first industrial use in 1967. A broad range of immobilized GI products have been sold by producers like Genencor, DuPont, Novozymes SA, and Solvay, and continued progress in GI immobilization has yielded iterative improvements in the production of HFCS using immobilized GI as biocatalyst [5]. In most contemporary processes, HFCS is produced in continuous fixed bed reactors containing immobilized GI as catalytic packing, which results in a mixture of nearly $42 \%$ d-fructose, $50 \%$ d-glucose, and small amounts of other sugars, and a $55 \%$ mixture of $d$-fructose-required for commercial application as sweetener-is attained via chromatographic enrichment [5]. The success of immobilized GI is rooted in the biochemical properties of the enzyme as well as the technological developments that allowed for the commercialization of the immobilized enzyme-catalyzed process. Currently, the production of HFCS is the largest industrial process employing an immobilized biocatalyst, with a nearly 10 million tons produced per year [5]. Studies showed that the temperature-dependent position of isomerization equilibrium, along with the relatively high $K_{m}$ value of GI, were two of the biochemical factors that drove the development of an immobilized enzyme process to improve upon a free enzyme process. 
At higher temperatures the equilibrium of the isomerization is shifted to favor higher yields of fructose, so the use of thermostable immobilized enzyme allowed for improved yields of HFCS. Immobilized GI allowed for implementation in continuous processes, which proved to be advantageous, as the high-concentration throughput of substrate helped to overcome the low efficiency of enzyme-substrate binding indicated by the low $K_{m}$ of GI. Furthermore, the production cost of GI was significant at the time of development, as the immobilization of GI decreased the total amount required for HFCS production by allowing for enzyme reuse [5]. The GI-catalyzed process is being further researched for the employment of thermostable enzyme with good activity retention at $90^{\circ} \mathrm{C}$, at which point the equilibrium conditions shift such that a $55 \%$ mixture of fructose can be obtained, obviating the need for chromatographic enrichment in the process [5].

\section{Environmental Impact Assessment and Economic Approaches for Enzyme Implementation in Industrial Catalysis}

While the development of highly efficient immobilized biocatalyst is the short-term goal of lab-scale research, critical economic and environmental evaluations of immobilized enzyme-catalyzed processes are required to determine the suitability of an immobilized enzyme for scale-up [50-52]. In such a context, life-cycle assessments (LCAs) and techno-economic analyses (TEAs) are increasingly important tools as a growing number of immobilized enzymes are assessed for commercial-scale biocatalytic processes [5].

LCAs are used to identify process energy and material requirements, as well as waste and emissions, which are subsequently used to analyze the sustainability and environmental impact of a process. The use of enzymes in industrial processes is often associated with reduced consumption of energy, chemical inputs, and waste streams. For example, using phospholipase to degum vegetable oil led to a decrease of 44 tons of equivalent $\mathrm{CO}_{2}$ generation per 1000 tons of oil produced, due to improvement in oil yield and a subsequent decrease in feedstock requirements [5]. In another study, the enzymatic production of biodiesel reduced the amount of steam needed to preheat feedstock due to milder reaction conditions, and also improved each measure of environmental impact, including human toxicity, ozone depletion, and global warming potential [50]. Immobilized enzyme-catalyzed processes have been found to further reduce the environmental burden of free enzyme-catalyzed processes [51]. Raman et al. performed LCA on production of biofuel from alkali catalyst, free lipase, and immobilized lipase to determine an optimally sustainable process. Both free lipase and immobilized lipase reduced process energy consumption when scaled to $1000 \mathrm{~kg}$ per year production due to milder reaction conditions. Furthermore, the immobilized lipase was reported to improve the free-enzyme catalyzed process because its reuse reduced consumption of carbohydrates and the minerals required for its free form production [51]. The general decrease in material and energy consumption exhibited by enzymatic processes, as a result of reduction of energy consumption, indicates that biocatalytic processes are potentially both more environmentally benign and economically lucrative. However, LCA does not account for productivity or process economics, and thus is insufficient as a standalone metric for process implementation.

TEAs study the economic viability of a process based on technology readiness and process economics such as utilities, feedstocks, labor, and capital investments [52]. Olafsson et al. reported a TEA for a comparison of integrated and off-site cellulase catalysis in fermentation of lignocellulosic material for ethanol production. The authors found that off-site production of ethanol using similar technologies was a more economically competitive option due to the production of more marketable byproducts [52]. Analysis showed that while profitability remains the critical driving force of process development, TEAs and LCAs in combination are invaluable tools for the full diagnosis of both benefits and drawbacks associated with scale-up of biocatalytic processes. 


\section{Pertinent Examples of Enzymes Application in Industrial Catalysis}

\subsection{Pharmaceuticals Industry}

Enzyme catalysis has been successfully used for the production of pharmaceutically active chemicals at the industrial scale. The most significant advantages enzyme catalysis holds over conventional catalysis are the high regio-, chemo-, and stereoselectivities at which enzymes convert substrate to product $[2,123]$. A high degree of product specificity is largely desirable in such pharmaceutical processes due to the streamlining of product synthesis routes and subsequent improvement in process economics [8,30]. For example, the production of many pharmaceuticals requires the introduction and subsequent removal of protecting groups from pharmaceutically active ingredient intermediates to ensure adequate product selectivity. The use of appropriate enzymes not only obviates such steps, but has also been shown to yield higher enantiomeric excesses of desired stereoisomers [8]. Furthermore, enzyme-catalyzed synthesis routes often reduced or eliminated the need for chemically harsh substances or high-temperature conditions that can otherwise require intense process safety considerations [2].

The interdisciplinary approach that allowed for the economically advantageous implementation of biocatalysis on the industrial scale is highlighted by the development of the enzyme-catalyzed synthesis of sitagliptin, a drug marketed by Merck for type II diabetes treatment [31]. Sitagliptin is a dipeptidyl peptidase-4 inhibitor that prevents an increase in the blood-retinal barrier and inhibits diabetes-induced tight junction disassembly [32]. Conventional synthesis of sitagliptin requires a high-pressure hydrogenation of enamine via a rhodium-based catalyst and subsequent carbon treatment to remove trace amounts of rhodium, yielding sitagliptin in $97 \%$ enantiomeric excess (e.e.) [100]. Research teams at Codexis and Merck conducted extensive protein engineering to produce an R-selective transaminase (R-ATA) from Arthrobacter sp. capable of converting $200 \mathrm{~g}$ $\mathrm{L}^{-1}$ of prositagliptin ketone to sitagliptin in dimethyl sulfoxide (DMSO) in greater than $99.95 \%$ e.e. [33]. In addition to a yield of higher enantiomeric purity, the enzyme-catalyzed route had $10 \%$ increased yield and a 53\% increase in productivity ( $\mathrm{kg}$ sitagliptin $\mathrm{L}^{-1}$ day $^{-1}$ ), and also eliminated the need for a rare heavy metal-based catalyst that necessitated purification and special equipment necessary for high-pressure operation [31].

Codexis and Merck have also invested heavily in research for scale-up of a monoamine oxidase (MAO)-catalyzed process for enantiomerically pure desymmetrization of a bicyclic proline intermediate, an important precursor in the synthesis of boceprevir, a NS3 protease inhibitor used for treatment of chronic hepatitis $C$ infections [2,34]. Conventional synthesis of bicyclic proline is an intensive process requiring an excess of metal-based oxidant and reductant through 8 reaction steps; the enantioselective, MAO-catalyzed synthesis of the intermediate is an attractive alternative with the potential to greatly reduce operation time and waste generation [30]. Although significant improvements in MAO activity, solubility, and thermostability were achieved through protein engineering via 4 rounds of evolution involving the introduction of random mutations and subsequent screening for desired phenotypes, the addition of bisulfate to the MAO-catalyzed process for the capture of imine compounds was necessary to mitigate its irreversible inhibition [30].

The combination of biocatalysts genetically, engineered for robust catalytic capabilities and topological process optimizations, illustrates the overlap of technical expertise needed for successful scale-up of enzyme catalysis [2,5]. As such, the enzyme-catalyzed process showed several marked improvements over the conventional synthesis of the intermediate when compared at the same scale, namely decreases of $59.8 \%$ in raw materials, $32.8 \%$ in water, and $63.1 \%$ in process waste per unit of product synthesized [30]. Though further work is needed for economically feasible industrial-scale implementation, the comparison between the conventional synthesis and the MAO-catalyzed synthesis route suggests that enzyme catalysis could greatly improve over current industry standards and outcomes. 
In a study by Hayes et al., authors reported an improved commercial-scale synthesis route for $(S, S)$-reboxetine succinate, a noradrenergic anti-depressant for the treatment of fibromyalgia in the latter stages of development at Pfizer $[35,36]$. The production of reboxetine requires an acetylation of diol intermediate. However, conventional synthesis routes rely on classical chemical acetylation that suffers from di-acetylation and poor enantioselectivity, therefore generating considerable amounts of unwanted byproducts [2]. The proposed generation synthesis route successfully employed Candida antartica lipase B, an active, commercially available enzyme, for the highly enantioselective acetylation of diol intermediate [36]. The lipase-catalyzed process resulted in the selective mono-acetylation of diol intermediate with $98 \%$ regioselectivity and greater than $99 \%$ yield. Furthermore, it was possible for the enzyme to be removed from the reaction mixture via simple filtration, and it thus maintained high regioselectivity at the lab scale upon reuse, all at low costs [36]. As such, the new generation synthesis route resulted in a 58\% improvement in the commercial product yield of $(S, S)$-reboxetine succinate and a nearly $1300 \mathrm{MT}_{\text {year }}{ }^{-1}$ reduction in process waste at peak process throughput [36].

Because lipases can hydrolyze a broad spectrum of substrates, they have been researched as biocatalysts for many other pharmaceutical syntheses [7,36,37]. Martinez et al., for instance, proposed a new-generation synthesis route for the industrial-scale production of pregabalin, a neuroactive drug exhibiting anticonvulsant, pain killing, and anti-anxiety activity used for the treatment of epilepsy, anxiety, and social phobia [37,38]. The proposed route utilized lipolase, a commercially available lipase, for the selective hydrolysis and subsequent separation of the $S$-enantiomer intermediate from the $R$-enantiomer for conversion to pregabalin via decarboxylation [37]. While screening for industrial enzyme increased selectivity and reduced waste generation, several process optimizations allowed for the improved process economics of such a new-generation route. The addition of $\mathrm{Ca}^{2+}$ and $\mathrm{Zn}^{2+}$ mitigated lipolase inactivation by forming complexes with chemical species that acted as enzyme inhibitors. In addition, the rapid phase splitting of S-enantiomer from R-enantiomer enabled racemization and thus efficient reuse of starting material [37]. The new-generation synthesis route resulted in a $40-45 \%$ increase in yield of pregabalin at $99.5 \%$ purity and $99.75 \%$ e.e. Furthermore, the amount of waste generated per kilogram of product yielded was calculated to be just $20 \%$ that of the classical route [37].

\subsection{The Food-Water-Fuel Nexus}

The large-scale production of biofuels, i.e., fuels derived from biomass, animal fats, waste oils, and other renewable resources that encompass chemical products such as bioalcohols, biodiesel, biosynthetic oils, and biogas, has been recognized for its potential to supplement or replace fossil fuels, particularly as oil reserves are depleted to meet global energy demands [18,49]. The benefits of economically feasible biofuel production are two-fold: biofuel offers improved sustainability over traditional fuel sources as well as significantly reduces the environmental impact owing to its lower emission of carbon monoxide, nitrogen oxides, sulfur oxides, and particulate matter [18]. According to British Petroleum (BP), global production of biofuels rose by an average of $14.1 \%$ from 2006 to 2016, illustrating the growing impact that biofuels have on the world energy landscape [124]. While government incentives have helped to drive industry-scale biofuel production, the economic viability of biofuel production will be determined by the development of processes that efficiently use waste from agriculture and industry as feedstock, thus side-stepping the ethical dilemma of using fresh water and land resources for fuel production [125]. Numerous technologies exist for the conversion of raw biological materials to usable, high-energy bioproducts with most production routes requiring either the transesterification of oils or the esterification of fatty acids $[5,18]$. The traditional chemical process uses sodium methoxide for conversion of plant oil triglycerides to fatty acid methyl esters (FAMEs), which subsequently results in a product contaminated with high alkali salt content requiring costly purification [5]. 
The use of lipase as a biocatalyst for esterification was researched for its efficiency at mild reaction conditions and high-purity product yields and was proposed to eliminate the need for purification. However, for biofuel production, economical implementation of such an enzymatic process requires efficient recovery and reuse of lipase due to the required scale of production, therefore necessitating an immobilized enzyme [5,49].

A prominent trend in the production of biofuels is the design of processes based on inexpensive, largely abundant starting materials because cheap feedstock is one of the biggest driving forces in the profitability of biofuels processes [19]. The biggest such feedstock is lignocellulosic biomass-made up of lignin, cellulose, and hemicellulose - due to its massive abundance and wide range of sources including crop residues, softwood and hardwood, herbaceous biomass, and municipal solid waste [19]. The most difficult technical barrier required to unlock lignocellulosic biomass is however the extensive mechanical or chemical pretreatment required to further enable the processing of cellulose in lignocellulosic biomass via hydrolysis to glucose and subsequent conversion to bioethanol via whole-cell fermentation [126-128]. Current research suggests that ionic liquids, i.e., salts that exist in molten states at temperatures below $100^{\circ} \mathrm{C}$ with strong chemical and thermal stabilities and extremely low vapor pressures, will play a key role in the development of processes that viably release cellulose from lignocellulosic material [126-128].

Chemical conversion of cellulose to glucose requires the use of diluted acids and high temperatures, which implies high energy inputs to result in the generation of a significant amount of unwanted byproducts [19]. A more ideal approach is the use of cellulase, i.e., a mixture of hydrolytic enzymes that act synergistically in the conversion of cellulosic material, for the selective enzymatic hydrolysis of cellulose to glucose, which requires longer reaction time but leads to improved yield from the subsequent fermentation due to a low generation of unwanted byproduct [19,53-55]. The economically viable scale-up of cellulase-catalyzed cellulose conversion to glucose for bioethanol production is limited by poor biocatalyst recovery, slow enzyme-catalyzed reaction rates, and low biocatalyst stability under industrial operation conditions $[54,55]$. Therefore, immobilized cellulase is a requirement for industrial catalysis, particularly considering the acid pretreatment required for cellulose [55].

Reported lab-scale work on the immobilization of cellulase illustrates the potential for the employment of cellulase for biodiesel production. Khorshidi et al., for instance, showed that immobilized cellulase was significantly more active than free cellulase at lower $\mathrm{pH}$ conditions and at higher temperatures, showing that the immobilization technique can functionalize biocatalyst at industrial conditions [54]. Lima et al. found that immobilized cellulase had increased thermostability when compared to free cellulase and retained nearly $70 \%$ of its initial activity after eight cycles of converting cellulosic biomass to glucose. The significant activity retention of immobilized cellulose suggests that immobilization techniques can improve process economics by allowing for efficient reuse of biocatalyst [56].

In 2006, Hainabaichuan Co. Ltd. (Guangzhou, China) began processing waste palm oils and waste edible oils for lipase-catalyzed production of 20,000 tons of biodiesel per year and subsequent scale-up to 40,000 tons per year in 2008 [49]. Lvming Environmental Technology Co. Ltd.(Shanghai, China) implemented a commercially available immobilized lipase as a catalyst in a FAME production line with an annual capacity of 10,000 tons in 2007 [57]. The enzymatic reaction, designed for a feedstock of high acid value (AVN160 $\mathrm{mg} \mathrm{KOH} \mathrm{g}^{-1}$ ) waste cooking oil, was carried out in a stirred tank reactor at an enzyme loading of $0.4 \%$ relative to charged substrate, which led to a FAME yield of $90 \%$ at optimal conditions [57]. Piedmont Biofuels announced in 2012 the successful scale-up of a continuous enzymatic transesterification of free fatty acids (FFAs) via immobilized Candida antarctica lipase B for biodiesel production; the enzymatic reaction eliminated the need for caustic stripping of the chemical intermediate due to its high product selectivity [5].

\subsection{Natural Gas Conversion}

Recent advances in the extraction and recovery of natural gas resources have made accessible vast reserves of natural gas in North America [129]. A review of world energy production and energy 
markets by BP reported a proven reserve of nearly 8.7 trillion $\mathrm{m}^{3}$ of natural gas in the US alone [124]. Additionally, production of natural gas in the US comprises over $20 \%$ of global natural gas production at 750 billion $\mathrm{m}^{3}$ in 2016 [124].

The composition of natural gas is $80-95 \%$ methane with varying degrees of heavier hydrocarbons, but methane has a relatively low market value due to difficulties in storage and transportation as well as limited use as fuel $[129,130]$. The low market value and high greenhouse gas potential of methane have initiated a surge in research and development of technologies that can be employed to convert methane to high-quality, value-added chemicals.

Much current research on the economically viable use of methane as feedstock is focused on conversion to methanol, which can be more readily converted to olefins and other valuable hydrocarbons [130,131]. Current processes for a traditional chemical conversion of methane to methanol, such as steam reformation and the Fischer-Tropsch process, are limited by several significant drawbacks. The chemical conversion route requires the use of high-temperature, high-pressure unit operations as well as noble metal catalysts, resulting in a poor selectivity of methanol [130]. The low yield of methanol necessitates a large process throughput in order to overcome large capital cost investments, thus the process is only profitable at a massive scale, thus placing further constrictions on process employment due to the difficulty of transporting methane from an extraction site to a production plant $[129,130]$.

The use of the biocatalyst methane monooxygenase (MMO), for the conversion of methane to methanol, has recently gained interest in the wave of expanding natural gas extraction. MMO has been shown to convert methane to methanol at ambient conditions with selectivity approaching $100 \%$ and thus has been researched for the scale-up of methane conversion, considering its multiple advantages over the chemical conversion route [14,129-131]. The high selectivity of MMO-catalyzed methanol production eases the intensity of product separation and could significantly reduce the number of steps required in the conversion process. Furthermore, the enzymatic reaction occurs at mild reaction conditions, and could thus cut back on costs associated with heating, pressurization, and other feedstock conditioning steps $[129,130]$.

Much lab-scale research remains to assess the MMO-catalyzed conversion of methane for industrial applications because isolation of $\mathrm{MMO}$ is an intensive process, suggesting it may be beneficial to immobilize the enzyme for reuse. Blanchette et al. reported the use of a 3D printed microbioreactor with immobilized MMO as packing for continuous methane conversion to methanol. Although immobilized MMO retained good activity through 20 consecutive reuses, the overall product yield was significantly less than the biocatalytic mass required for methane conversion [129]. Ultimately, enzymatic conversion of methane to methanol is a developing technology with several major hurdles to overcome before successful economic scale-up. Due to the inexpensive costs of methane and methanol, enzyme-catalyzed process must be efficient to ensure economic viability. Currently, low catalytic activity of MMO is a significant limiting factor [14,15,129-131]. Furthermore, a more intensive examination of process configurations is required to mitigate the mass transfer limitations that arise from the low solubility of oxygen and methane in aqueous media [130].

\subsection{Food and Beverage Industry}

In many instances, traditional chemical synthesis routes are not viable for food products due to reagent toxicity and complex reaction chemistries that result in unfavorable process economics [11]. Biocatalysts, on the other hand, present an opportunity for simplified, efficient production routes that mitigate the need for harsh substances, and thus are more economically competitive [9-11,132]. As such, the use of biocatalysts in food and beverage processes dates back thousands of years to the advents of culinary practices like wine and cheese making [10]. In modern times, the widespread use of enzymes in food and beverage industries for food quality preservation or modification is one of the earliest successful industrial applications of biocatalysis, observed in beer fermentation, juice debittering, and bread baking [133]. The replacement of conventional chemical treatment with enzyme-catalyzed pathways for conversion of starch to glucose and fructose first took place several decades ago [12,122]. 
The conventional production route requires temperatures up to $175^{\circ} \mathrm{C}$ and considerable pressurization, whereas biocatalytic processes can be carried out at temperatures near $100^{\circ} \mathrm{C}$ and at ambient pressure via sequential $\alpha$-amylase-catalyzed reactions encompassing both liquefaction and saccharification steps [122]. In addition to milder reaction conditions, the multi-enzymatic process resulted in higher product selectivity and therefore allowed for better defined production routes for varying sugar products like maltose, fructose syrup, and crystalline sugar, as dictated by biocatalyst selection [122].

An emerging trend is the use of enzyme catalysis for commercial-scale production of probiotics, artificial sweeteners, and rare sugars [2]. Probiotics, such as oligosaccharides, lactulose, lactilol hydrolysates, and inulin, are non-digestible food additives that stimulate growth of gut bacteria and can reportedly improve human health $[2,9,133]$. Dietary supplement producers have become particularly interested in simple, efficient enzyme-catalyzed synthesis routes of probiotics due to above-average projected market growth and accompanying increase in demand [2,9]. Yakult Honsha Co. Ltd. of Japan and Friesland Food Domo of The Netherlands, among others, have carried out commercial-scale, enzyme-catalyzed production of galacto-oligosaccharides (GOS), a lucrative probiotic with digestive health benefits and use as low-calorie sweeteners [9]. GOS are produced by transgalactosylation simultaneous to hydrolysis of lactose via $\beta$-galactosidase; lab-scale results have shown GOS yields near $40 \%$ for free enzyme, while immobilized enzymes show the potential for larger yields of up to $50 \%$ through implementation in a continuous system resulting in decreased product inhibition [9].

The enzymatic production of protein hydrosylates for use as nutritional supplements and flavor enhancers has been developed due to milder reaction conditions and increased control over product formation relative to traditional chemical routes [133]. When hydrolyzed, a parent protein forms biofunctional peptides exhibiting antioxidant, antimicrobial, and antihypertensive properties, among other therapeutic effects $[132,133]$. The production of fish protein hydrolysates from seafood processing waste via papain, a proteolytic enzyme derived from papaya that has found widespread industrial application, has garnered attention recently because the process is a potential solution for minimizing pollution from fishing industries [39]. Additionally, papain has been researched as a biocatalyst for production of protein hydrosylates from Chinese walnuts; lab-scale work on papain catalysis has shown moderate yields and purities of hydrosylates, and peptides obtained from produced hydrosylates showed good antioxidant properties [40].

\subsection{Flavors and Aromas Industry}

Biocatalytic processes economically and environmentally advantageous to conventional chemical processes are in development for commercial-scale production of fragrance compounds, flavor compounds, and aromatics. The chemical structures of such substances are often characterized by regio-, chemo-, or stereoselective positioning of functional groups like alcohols, aldehydes, ketones, and esters; thus, scale-up of efficient enzyme-catalyzed processes for production of aromatic compounds is a potentially lucrative endeavor, particularly in light of promising global market projections for flavors and fragrances [42].

Lipase enzymes play an integral role in the development of biocatalytic fragrance and flavor production due to its capability to transfer acyl groups from esters to other nucleophiles [42]. Though most progress has been in bench-scale synthesis of aroma esters, the results suggest that a combination of protein engineering and process engineering can facilitate scale-up to profitable industrial processes. For instance, Vosmann et al. achieved a $94 \%$ conversion of oleic acid selectively to benzyl oleate with benzyl alcohol as an acyl acceptor in $1 \mathrm{~h}$ using a commercially available lipase, which illustrates strong product specificity that could make enzymatic conversion advantageous [41]. Badgujar et al. reached $99 \%$ conversion of vinyl propionate to p-cresyl propionate in $1.5 \mathrm{~h}$ via immobilized lipase in heptane, highlighting that certain immobilization techniques could functionalize lipase for implementation in industrial environments [43]. However, further work to achieve more efficient, robust biocatalytic reactions is required before enzymatic production of aromatic esters can be scaled to larger process throughputs [41-43]. 


\subsection{Detergents Industry}

Successful employment of biocatalysts is cited as the driving force of production of cost effective, environmentally benign detergents [44]. In the instance of the detergents industry it should be noted that enzymes are a product rather than a chemical process-specific catalyst. Nonetheless, favorable market trends in the detergents' industry reinforce the underlying view that biocatalytic products are inherently safer and more sustainable than traditional chemical products that pose health and safety risks [44-46]. Alkaline proteases-which are effective in the removal of protein stains and the cleaving of damaged cotton fibers-isolated from microbial sources comprise significant portions of multiple detergents produced and sold at commercial scale by manufacturers like Novozymes SA, Kao Corporation, and Genecor International [45]. The high reaction specificity of enzymatic reactions further mitigates damage to fabrics and surfaces that is characteristic of chemically harsh detergent agents [47]. Furthermore, the ratio of catalytically active enzymes in detergent mixtures are optimized for specific detergent applications; for instance, dishwashing detergents often contain varying degrees of amylase and lipase intended for the removal of starch food deposits and fats and oils, respectively $[47,48]$.

\section{Projections of Economic Growth and Implementation Potential}

The market for industrially relevant enzymes-including those applied in food, animal feed, detergent, and technical industries-is expected to grow globally through 2021 at an annual growth rate of $4.7 \%$. Development of novel enzyme technologies, increased demand for naturally made food products, and policy requiring larger shares of renewable energy sources like biofuels [44] are not only becoming an alternative but an implementation reality. Of these categories, enzymes used in technical industries such as papers, textiles, leathers, and biofuels comprise the greatest potential for use of immobilized biocatalysts owing to process-oriented application [44]. Thus, market projections for technical enzymes are a reasonable indicator of process development for biocatalytic processes designed for commercial-scale production lines.

The most significant driving force in projected market growth for technical enzymes is renewed interest in enzyme-catalyzed biofuel production using lignocellulosic materials, which is a direct result of stricter environmental regulations [44]. In this regard, enzymes used in biofuels processes represent the largest portion of the technical enzyme market, which is dominated by two major players, Novozymes and Danisco/DuPont [44]. In 2015, DuPont and Quad County Corn Processors signed a multiyear contract for the production of bioethanol from cellulosic material in corn kernel fiber; the same year, DuPont acquired enzyme production technology assets from Dyadic, which is expected to further drive process development in the technical enzyme sector [44]. The same technologies are being investigated for further integration into paper and pulp industries, where xylanase, catalase, and lipase are frequently used for biomechanical pulping, de-inking of recycled fibers, and modification of fiber properties [58-61].

The bulk of the global technical enzyme market is reported for markets in Europe, the Middle East, and Africa (EMEA) at nearly 35\% of the global share in 2016 [44]. However, strong market growth is projected for North America and Asia-Pacific, with annual growth rates of $6.8 \%$ for North America and $7.9 \%$ for the Asia-Pacific region through 2021 (Figure 3) [44]. Furthermore, the technical enzyme market is expected to overtake the EMEA market as the largest global segment of the market by 2021, suggesting progress in process development will largely take place in the Asia-Pacific region and in North America through 2021 [44].

If further progress is to be achieved, optimizing the structure-function relationships of enzyme-based conjugates while minimizing the production costs of the individual components (i.e., support and biocatalysts), as well as the implementation costs of the biocatalytic process is imperious (Figure 4). The modification of conventional schemes for enzyme immobilization and integration will not only need to facilitate product yield but, furthermore, optimize the process' metrics to thus limit logistical burden to both the environment and the individual [134-136]. Coupling or transient enzyme-driven reactions will also aim to reduce any public pressure associated with implementation of fossil fuels and thus lead a safer and eco-friendly solution for industrial revolution. 
The challenges and opportunities associated with enzyme catalysis implementation will not only have to consider profit and marketability, but it will further have to consider integration of biomimetic approaches or "one pot" processes that could allow for efficiency, profitability, reusability and stability, all under the complexity of multi-chain driven specific reactions.

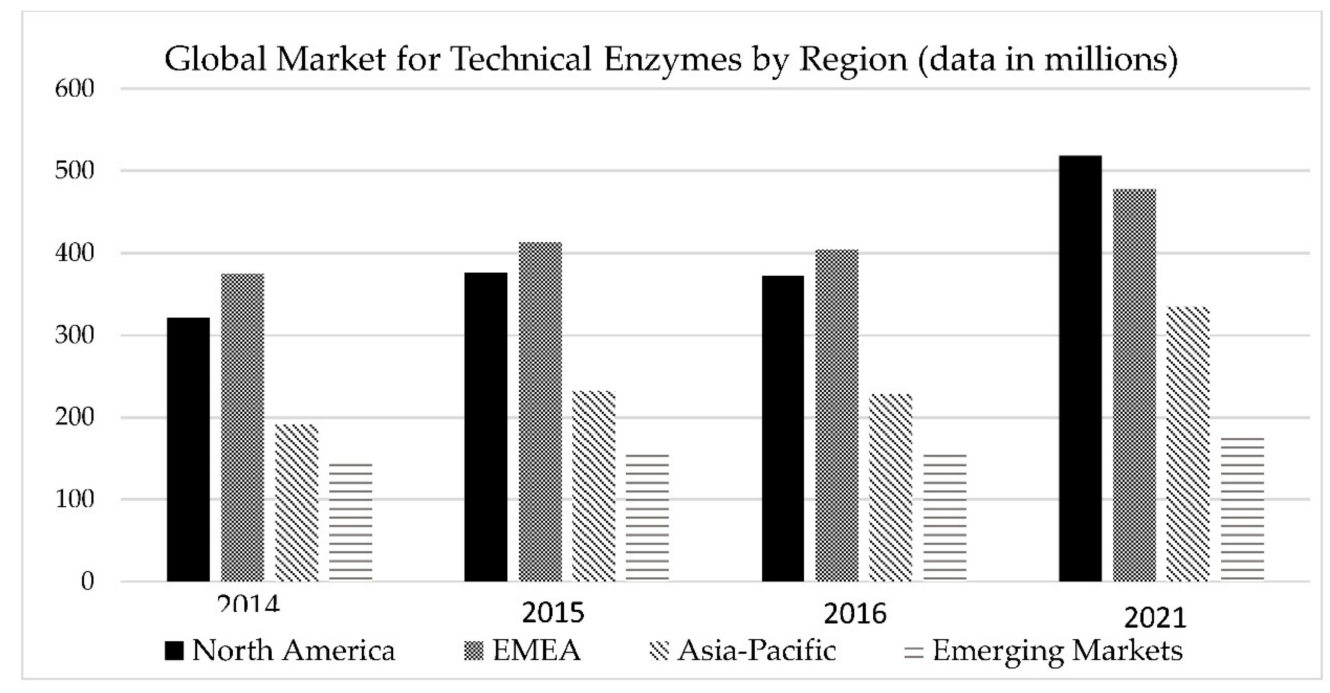

Figure 3. Global market growth projections for technical enzymes by geographical regions.

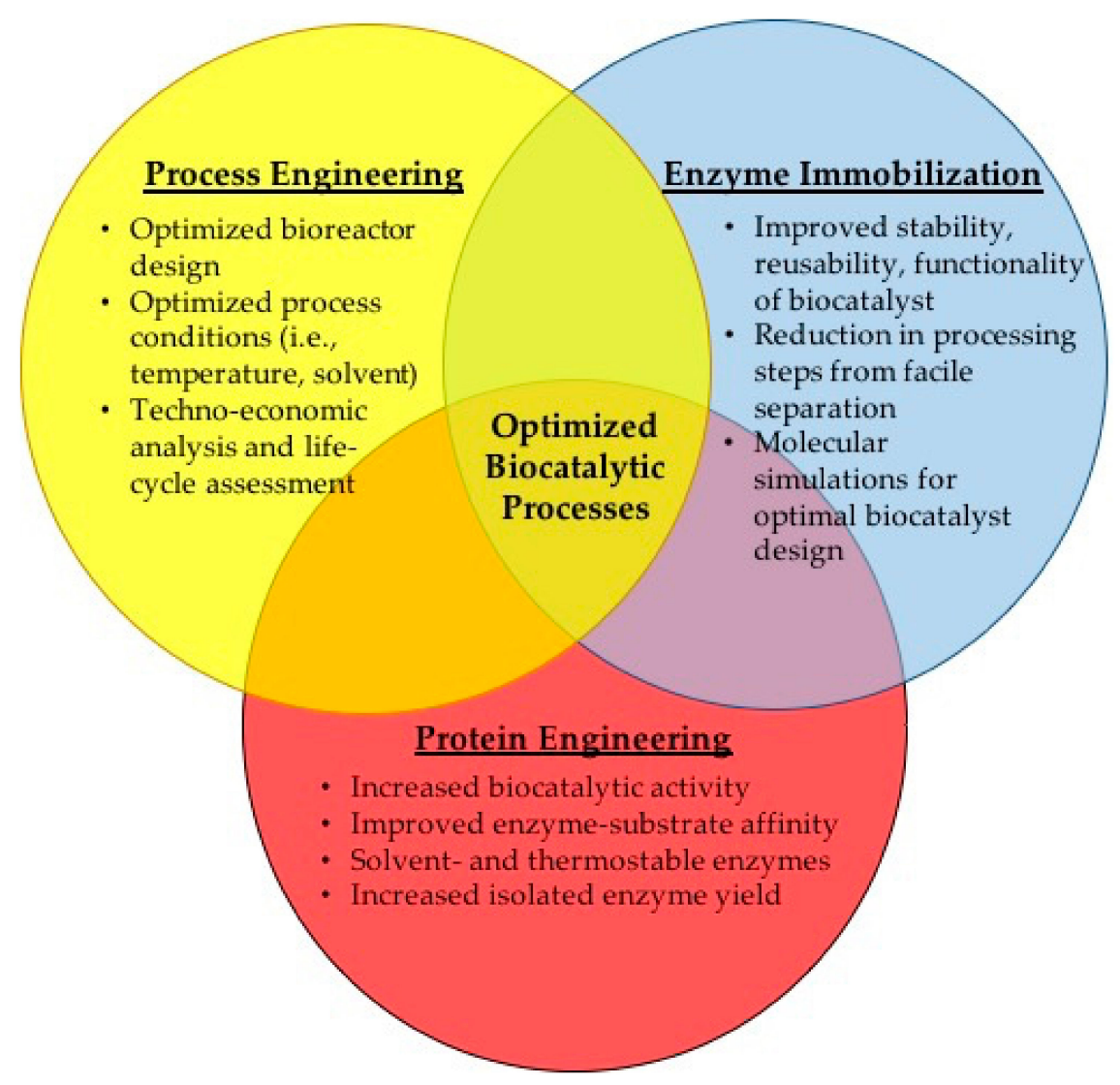

Figure 4. Schematic representation of a multidisciplinary approach aimed to define optimal biocatalytic processes. Implementation of biocatalysts in industrial technologies will have to not only consider optimization of the enzyme functionality but further, lead to increase in enzyme operational stability at the interface with supports used for immobilization. 


\section{Conclusions}

Commercial-scale enzyme catalysis has been implemented in several industries such as pharmaceutical and foods with recent trends for biofuel production and natural gas conversion. Product yield in such industries was shown to be governed by enzymatic catalysis being implemented in milder process conditions and under less energy consumption, with reduced waste generation, exceptional high product selectivity to result in improvements in process economics and environmental sustainability.

The scale-up of enzymatic processes is however largely hampered by limitations in biocatalyst stability. To that end, enzyme immobilization was proposed and researched as an attractive approach for expanding the scope of enzyme catalysis and improved process efficiency. Critical examination of strategies for immobilization are still need to facilitate the development of optimal enzymes while holistic knowledge of economic driving forces to surround process development are still required for appropriateness of enzyme catalysis implementation in commercial-scale processes. The successful industrial application of new generation immobilized biocatalysts ultimately will be defined by critical analysis of immobilized enzyme processes, where overlap of expertise in protein engineering, enzyme immobilization, process engineering and life cycle analysis is paramount. Future implementation prospects will need to account for the structure-function relationship both at the level of the enzyme and the platform used in the immobilization as well as the optimized product yield at low implementation costs and with conjunction of experimental and computational approaches for an integrated combinatorial strategy.

Author Contributions: Proposed conceptualization of the paper: J.C; Feedback on the conceptualization: C.Z.D. and A.E.I; Writing of the paper draft: J.C.; J.C., C.Z.D. and A.E.I revised the manuscript; All authors have approved the final manuscript.

Funding: This work was funded by the National Science Foundation (NSF) grant 1454230.

Acknowledgments: The authors acknowledge the work of Xiao Hu for Figure 2. Molecular graphics were performed with the UCSF Chimera package. Chimera is developed by the Resource for Biocomputing, Visualization, and Informatics at the University of California, San Francisco (supported by NIGMS P41-GM103311).

Conflicts of Interest: The authors declare no conflict of interest.

\section{References}

1. Bommarius, A.S.; Paye, M.F. Stabilizing biocatalysts. Chem. Soc. Rev. 2013, 42, 6534-6565. [CrossRef] [PubMed]

2. Choi, J.-M.; Han, S.-S.; Kim, H.-S. Industrial applications of enzyme biocatalysis: Current status and future aspects. Biotechnol. Adv. 2015, 33, 1443-1454. [CrossRef] [PubMed]

3. Madhavan, A.; Sindhu, R.; Binod, P.; Sukumaran, R.K.; Pandey, A. Strategies for design of improved biocatalysts for industrial applications. Bioresour. Technol. 2017, 245, 1304-1313. [CrossRef] [PubMed]

4. Roy, I.; Prasad, S. Converting Enzymes into Tools of Industrial Importance. Recent Pat. Biotechnol. 2017, 12, 33-56.

5. DiCosimo, R.; McAuliffe, J.; Poulose, A.J;; Bohlmann, G. Industrial use of immobilized enzymes. Chem. Soc. Rev. 2013, 42, 6437-6474. [CrossRef] [PubMed]

6. Sun, H.; Zhang, H.; Ang, E.L.; Zhao, H. Biocatalysis for the synthesis of pharmaceuticals and pharmaceutical intermediates. Bioorgan. Med. Chem. 2017, 26, 1275-1284. [CrossRef] [PubMed]

7. Patel, R.N. Biocatalysis for synthesis of pharmaceuticals. Bioorganic Med. Chem. 2017, 26, 1252-1274. [CrossRef] [PubMed]

8. Huisman, G.W.; Collier, S.J. On the development of new biocatalytic processes for practical pharmaceutical synthesis. Curr. Opin. Chem. Biol. 2013, 17, 284-292. [CrossRef] [PubMed]

9. Panesar, P.S.; Kumari, S.; Panesar, R. Biotechnological approaches for the production of prebiotics and their potential applications. Crit. Rev. Biotechnol. 2013, 33, 345-364. [CrossRef] [PubMed]

10. Fernandes, P. Enzymes in Food Processing: A Condensed Overview on Strategies for Better Biocatalysts. Enzyme Res. 2010. [CrossRef] [PubMed] 
11. Akoh, C.C.; Chang, S.-W.; Lee, G.-C.; Shaw, J.-F. Biocatalysis for the Production of Industrial Products and Functional Foods from Rice and Other Agricultural Produce. J. Agric. Food Chem. 2008, 56, 10445-10451. [CrossRef] [PubMed]

12. Kapoor, S.; Rafiq, A.; Sharma, S. Protein engineering and its applications in food industry. Crit. Rev. Food Sci. Nutr. 2017, 57, 2321-2329. [CrossRef] [PubMed]

13. Pellis, A.; Cantone, S.; Ebert, C.; Gardossi, L. Evolving biocatalysis to meet bioeconomy challenges and opportunities. New Biotechnol. 2018, 40, 154-169. [CrossRef] [PubMed]

14. Strong, P.J.; Kalyuzhnaya, M.; Silverman, J.; Clarke, W.P. A methanotroph-based biorefinery: Potential scenarios for generating multiple products from a single fermentation. Bioresour. Technol. 2016, 215, 314-323. [CrossRef] [PubMed]

15. Fei, Q.; Guarnieri, M.T.; Tao, L.; Laurens, L.M.L.; Dowe, N.; Pienkos, P.T. Bioconversion of natural gas to liquid fuel: Opportunities and challenges. Biotechnol. Adv. 2014, 32, 596-614. [CrossRef] [PubMed]

16. Noraini, M.Y.; Ong, H.C.; Badrul, M.J.; Chong, W.T. A review on potential enzymatic reation for biodiesel production from algae. Renew. Sustain. Energy Rev. 2014, 39, 24-34. [CrossRef]

17. Asgher, M.; Shahid, M.; Kamal, S.; Iqbal, H.M.N. Recent trends and valorization of immobilization strategies and ligninolytic enzymes by industrial biotechnology. J. Mol. Catal. B Enzym. 2014, 101, 56-66. [CrossRef]

18. Liew, W.H.; Hassim, M.H.; Ng, D.K.S. Review of evolution, technology and sustainability assessments of biofuel production. J. Clean. Prod. 2014, 71, 11-29. [CrossRef]

19. Cardona, C.A.; Quintero, J.A.; Paz, I.C. Production of bioethanol from sugarcane bagasse: Status and perspectives. Bioresour. Technol. 2010, 101, 4745-4766. [CrossRef] [PubMed]

20. Grigoras, A.G. Catalase immobilization-A review. Biochem. Eng. J. 2017, 117, 1-20. [CrossRef]

21. Cao, S.; Xu, P.; Ma, Y.; Yao, X.; Yao, Y.; Zong, M.; Li, X.; Lou, W. Recent advances in immobilized enzymes on nanocarriers. Chin. J. Catal. 2016, 37, 1814-1823. [CrossRef]

22. Ansari, S.A.; Husain, Q. Potential applications of enzymes immobilized on/in nano materials: A review. Biotechnol. Adv. 2012, 30, 512-523. [CrossRef] [PubMed]

23. Misson, M.; Zhang, H.; Jin, B. Nanobiocatalyst advancements and bioprocessing applications. Interface 2015, 12, 20140891. [CrossRef] [PubMed]

24. Sheldon, R.A. Enzyme Immobilization: The Quest for Optimum Performance. Adv. Synth. Catal. 2007, 349, 1289-1307. [CrossRef]

25. Mehta, J.; Bhardwaj, N.; Bhardwaj, S.K.; Kim, K.-H.; Deep, A. Recent advances in enzyme immobilization techniques: Metal-organic frameworks as novel substrates. Coord. Chem. Rev. 2016, 322, 30-40. [CrossRef]

26. Cipolatti, E.P.; Valerio, A.; Henriques, R.O.; Moritz, D.E.; Ninow, J.L.; Freire, D.M.G.; Manoel, E.A.; Fernandez-Lafuente, R.; Oliveira, D.D. Nanomaterials for biocatalyst immobilization-State of the art and future trends. RSC Adv. 2016, 6, 104675-104692. [CrossRef]

27. Bezerra, C.S.; Lemos, C.M.G.D.F.; Sousa, M.D.; Goncalves, L.R.B. Enzyme immobilization onto renewable polymeric matrixes: Past, present and future trends. J. Appl. Polym. Sci. 2015, 132. [CrossRef]

28. Tracewell, C.A.; Arnold, F.H. Directed enzyme evolution: Climbing fitness peaks on amino acid at a time. Curr. Opin. Chem. Biol. 2009, 13, 3-9. [CrossRef] [PubMed]

29. Chao, F.-A.; Morelli, A.J.C.H., III; Churchfield, L.; Hagmann, L.N.; Shi, L.; Masterson, L.R.; Sarangi, R.; Veglia, G.; Seelig, B. Structure and dynamics of a primordial catalytic fold generated by in vitro evolution. Nat. Chem. Biol. 2013, 9, 81-83. [CrossRef] [PubMed]

30. Li, T.; Liang, J.; Ambrogelly, A.; Brennan, T.; Gloor, G.; Huisman, G.; Lalonde, J.; Lekhal, A.; Mijts, B.; Muley, S.; et al. Efficient, chemoenzymatic process for manufacture of the boceprevir bicyclic [3.1.0]proline intermediate based on amine oxidase-catalyzed desymmetrization. J. Am. Chem. Soc. 2012, 134, 6467-6472. [CrossRef] [PubMed]

31. Desai, A.A. Sitagliptin manufacture: A compelling tale of green chemistry, process intensification, and industrial asymmetric catalysis. Angew. Chem. Int. Ed. 2011, 50, 1974-1976. [CrossRef] [PubMed]

32. Goncalves, A.; Almeida, L.; Silva, A.P.; Fontes-Ribeiro, C.; Ambrosio, A.F.; Cristovao, A.; Fernandes, R. The dipeptidyl peptidase-4 (dpp-4) inhibitor sitagliptin ameliorates retinal endothelial cell dysfunction triggered by inflammation. Biomed. Pharmacother. 2018, 102, 833-838. [CrossRef] [PubMed]

33. Savile, C.K. Biocatalytic asymmetric synthesis of chiral amines from ketones applied to sitagliptin manufacture. Science 2010, 329, 305-309. [CrossRef] [PubMed] 
34. Kjellin, M.; Wesslen, T.; Lofblad, E.; Lennerstrand, J.; Lannergard, A. The effect of the first-generation hcv-protease inhibitors boceprevir and telaprevir and the relation to baseline ns 3 resistance mutations in genotype 1: Experience from a small swedish cohort. Upsala J. Med. Sci. 2018, 123, 50-56. [CrossRef] [PubMed]

35. Krell, H.V.; Leuchter, A.F.; Cook, I.A.; Abrams, M. Evaluation of reboxetine, a noradrenergic antidepressant, for the treatment of fibromyalgia and chronic low back pain. Psychosomatics 2005, 46, 379-384. [CrossRef] [PubMed]

36. Hayes, S.T.; Assaf, G.; Checksfield, G.; Cheung, C.; Critcher, D.; Harris, L.; Howard, R.; Mathew, S.; Regius, C.; Scotney, G.; et al. Commercial synthesis of (s,s0-reboxetine succinate: A journey to find the cheapest commercial chemistry for manufacture. Org. Process Res. Dev. 2011, 15, 1305-1314. [CrossRef]

37. Martinez, C.A.; Hu, S.; Dumond, Y.; Tao, J.; Kelleher, P.; Tully, L. Development of a Chemoenzymatic Manufacturing Process for Pregabalin. Org. Process Res. Dev. 2008, 12, 392-398. [CrossRef]

38. Marouf, H.M. Effect of Pregabalin Premedication on Emergence Agitation in Children after Sevoflurane Anesthesia: A Randomized Controlled Study. Anesth. Essays Res. 2018, 12, 31-35. [CrossRef] [PubMed]

39. Elavarasan, K.; Shamasundar, B.A. Effect of oven drying and freeze drying on the antioxidant and functional properties of protein hydrosylates derived from freshwater fish (Cirrhinus mrigala) using papain enzyme. J. Food Sci. Technol. 2016, 53, 1303-1311. [CrossRef] [PubMed]

40. Liu, M.-C.; Yang, S.-J.; Hong, D.; Yang, J.-P.; Liu, M.; Lin, Y.; Huang, C.-H.; Wang, C.-J. A simple and convenient method for the preparation of antioxidant peptides from walnut (Juglans regia L.) protein hydrosylates. Chem. Cent. J. 2016, 10, 39. [CrossRef] [PubMed]

41. Vosmann, K.; Wiege, B.; Weitkamp, P.; Weber, N. Preparation of lipophilic alkyl (hydroxy)benzoates by solvent-free lipase-catalyzed esterification and transesterification. Appl. Microbiol. Biotechnol. 2008, 80, 29-36. [CrossRef] [PubMed]

42. SA, A.G.A.; Meneses, A.C.D.; Araujo, P.H.H.D.; Oliveira, D.D. A review on enzymatic synthesis of aromatic esters used as flavor ingredients for food, cosmetics an pharmaceutical industries. Trends Food Sci. Technol. 2017, 69, 95-105. [CrossRef]

43. Badgujar, K.C.; Pai, P.A.; Bhanage, B.M. Enhanced biocatalytic activity of immobilized Pseudomonas cepacia lipase under sonicated condition. Bioprocess Biosyst. Eng. 2016, 39, 211-221. [CrossRef] [PubMed]

44. Dewan, S.S. Global Markets for Enzymes in Industrial Applications; BCC Research: Wellesly, MA, USA, 2017.

45. Kumar, D.; Savitri; Thakur, N.; Verma, R.; Bhalla, T.C. Microbial Proteases and Application as Laundry Detergent Additive. Res. J. Microbiol. 2008, 3, 661-672. [CrossRef]

46. Alfa, M.J.; Jackson, M. A new hydrogen peroxide-based medical-device detergent with germicidal properties: Comparison with enzymatic cleaners. AJIC 2001, 29, 168-177. [CrossRef] [PubMed]

47. Singh, R.; Kumar, M.; Mittal, A.; Mehta, P.K. Microbial enzymes: Industrial progress in 21st century. 3 Biotech 2016, 6, 174. [CrossRef] [PubMed]

48. Li, S.; Yang, X.; Yang, S.; Zhu, M.; Wang, X. Technology Prospecting on Enzymes: Application, Marketing and Engineering. Comput. Struct. Biotechnol. J. 2012, 2, e201209017. [CrossRef] [PubMed]

49. Zhang, B.; Weng, Y.; Xu, H.; Mao, Z. Enzyme immobilization for biodiesel production. Appl. Microbial. Biotechnol. 2012, 93, 61-67. [CrossRef] [PubMed]

50. Harding, K.G.; Dennis, J.S.; Blottnitz, H.V.; Harrison, S.T.L. A life-cycle comparison between inorganic and biological catalysis for the production of biodiesel. J. Clean. Prod. 2007, 16, 1368-1378. [CrossRef]

51. Raman, J.K.; Ting, V.F.W.; Pogaku, R. Life cycle assessment of biodiesel production using alkali, soluble and immobilized enzyme catalyst processes. Biomass Bioenergy 2011, 35, 4221-4229. [CrossRef]

52. Olofsson, J.; Barta, Z.; Borjesson, P.; Wallberg, O. Integrating enzyme fermentation in lignocellulosic ethanol production: Life-cycle assessment and techno-economic analysis. Biotechnol. Biofuels 2017, 10, 51. [CrossRef] [PubMed]

53. Yue, F.; Jian-xin, J.; Li-wei, Z. Recent developments in activities, utilization and sources of cellulase. For. Stud. China 2009, 11, 202-207.

54. Khorshidi, K.J.; Lenjannezhadian, H.; Jamalan, M.; Zeinali, M. Preparation and characterization of nanomagnetic cross-linked cellulase aggregates for cellulose bioconversion. J. Chem. Technol. Biotechnol. 2016, 91, 539-546. [CrossRef]

55. Taherzadeh, M.J.; Karimi, K. Enzyme-based hydrolysis processes for ethanol from lignocellulosic materials: A review. BioResources 2007, 2, 707-738. 
56. Lima, J.S.; Araujo, P.H.H.; Sayer, C.; Souza, A.A.U.; Viegas, A.C.; Oliveira, D.D. Cellulase immobilization on magnetic nanoparticles encapsulated in polymer nanospheres. Bioprocess Biosyst. Eng. 2017, 40, 511-518. [CrossRef] [PubMed]

57. Tan, T.; Lu, J.; Nie, K.; Deng, L.; Wang, F. Biodiesel production with immobilized lipase: A review. Biotechnol. Adv. 2010, 28, 628-634. [CrossRef] [PubMed]

58. Bhat, M.K. Cellulases and related enzymes in biotechnology. Biotechnol. Adv. 2000, 18, 355-383. [CrossRef]

59. Kuhad, R.C.; Gupta, R.; Singh, A. Microbial Cellulases and Their Industrial Applications. Enzyme Res. 2011, 2011. [CrossRef] [PubMed]

60. Hasan, F.; Shah, A.A.; Hameed, A. Industrial applications of microbial lipases. Enzyme Microb. Technol. 2006, 39, 235-251. [CrossRef]

61. Bajpai, P. Application of Enzymes in the Pulp and Paper Industry. Biotechnol. Prog. 1999, 15, 147-157. [CrossRef] [PubMed]

62. Sheldon, R.A. Characteristic features and biotechnological applications of cross-linked enzyme aggregates (cleas). Appl. Microbial. Biotechnol. 2011, 92, 467-477. [CrossRef] [PubMed]

63. Jesionowski, T.; Zdarta, J.; Krajewska, B. Enzyme immobilization by adsorption: A review. Adsorption 2014, 20, 801-821. [CrossRef]

64. Betancor, L.; Luckarift, H.R. Bioinspired enzyme encapsulation for biocatalysis. Trends Biotechnol. 2008, 26, 566-572. [CrossRef] [PubMed]

65. Feng, W.; Ji, P. Enzymes immobilized on carbon nanotubes. Biotechnol. Adv. 2011, 29, 889-895. [CrossRef] [PubMed]

66. Chauhan, G.S. Evaluation of nanogels as supports for enzyme immobilization. Polym. Int. 2014, 63, 1889-1894. [CrossRef]

67. Kommoju, P.R.; Chen, Z.W.; Bruckner, R.C.; Mathews, F.S.; Jorns, M.S. Probing oxygen activation sites in two flavoprotein oxidases using chloride as an oxygen surrogate. Biochemistry 2011, 50, 5521-5534. [CrossRef] [PubMed]

68. Li, Y.; Quan, J.; Branford-White, C.; Williams, G.R.; Wu, J.-X.; Zhu, L.-M. Electrospun polyacrylonitrileglycopolymer nanofibrous membranes for enzyme immobilization. J. Mol. Catal. B Enzym. 2012, 76, 15-22. [CrossRef]

69. Kumar, D.; Nagar, S.; Bhushan, I.; Kumar, L.; Parshad, R. Covalent immobilization of organic solvent tolerant lipase on aluminum oxide pellets and its potential application in esterification reaction. J. Mol. Catal. B Enzym. 2013, 87, 51-61. [CrossRef]

70. Tran, D.-T.; Chen, C.-L.; Chang, J.-S. Immobilization of Burkholderia sp. lipase on ferric silica nanocomposite for biodiesel production. J. Biotechnol. 2012, 158, 112-119. [CrossRef] [PubMed]

71. Premaratne, G.; Nerimetla, R.; Matlock, R.; Sunday, L.; Koralege, R.S.H.; Ramsey, J.D.; Krishnan, S. Stability, scalability, and reusability of a volume efficient biocatalytic system constructed on magnetic nanoparticles. Catal. Sci. Technol. 2016, 6, 2361-2369. [CrossRef] [PubMed]

72. Zhang, C.; Luo, S.; Chen, W. Activity of catalase adsorbed to carbon nanotubes: Effects of carbon nanotube surface properties. Talanta 2013, 113, 142-147. [CrossRef] [PubMed]

73. Edwards, J.V.; Prevost, N.T.; Condon, B.; French, A.; Wu, Q. Immobilization of lysozyme-cellulose amide-linked conjugates on cellulose I and II cotton nanocrystalline preparations. Cellulose 2012, 19, 495-506. [CrossRef]

74. Hong, J.; Xu, D.; Gong, P.; Yu, J.; Ma, H.; Yao, S. Covalent-bonded immobilization of enzyme on hydrophilic polymer covering magnetic nanogels. Microporous Mesoporous Mater. 2008, 109, 470-477. [CrossRef]

75. Zhu, J.; Sun, G. Lipase immobilization on glutaraldehyde-activated nanofibrous membranes for improved enzyme stabilities and activities. React. Funct. Polym. 2012, 72, 839-845. [CrossRef]

76. Ottone, C.; Bernal, C.; Serna, N.; Illanes, A.; Wilson, L. Enhanced long-chain fatty alcohol oxidation by immobilization of alcohol dehydrogenase from S. cerevisiae. Appl. Microbiol. Biotechnol. 2017, 102, 237-247. [CrossRef] [PubMed]

77. Kuo, C.-H.; Chen, G.-J.; Chen, C.-I.; Liu, Y.-C.; Shieh, C.-J. Kinetics and optimization of lipase-catalyzed synthesis of rose fragrance 2-phenylethyl acetate through transesterification. Process Biochem. 2014, 49, 437-444. [CrossRef] 
78. Tomke, P.D.; Rathod, V.K. Ultrasound assisted lipase catalyzed synthesis of cinnamyl acetate via transesterification reaction in a solvent free medium. Ultrason. Sonochemistry 2015, 27, 241-246. [CrossRef] [PubMed]

79. Eberhardt, A.M.; Pedroni, V.; Volpe, M.; Ferreira, M.L. Immobilization of catalase from Aspergillus niger on inorganic and biopolymeric supports for $\mathrm{H}_{2} \mathrm{O}_{2}$ decomposition. Appl. Catal. B Environ. 2004, 47, 153-163. [CrossRef]

80. Homaei, A.A.; Sajedi, R.H.; Sariri, R.; Seyfzadeh, S.; Stevanato, R. Cysteine enhances activity and stability of immobilized papain. Amino Acids 2010, 38, 937-942. [CrossRef] [PubMed]

81. Dincer, A.; Telefoncu, A. Improving the stability of cellulase by immobilization on modified polyvinyl alcohol coated chitosan beads. J. Mol. Catal. B Enzym. 2007, 45, 10-14. [CrossRef]

82. Lopez-Gallego, F.; Betancor, L.; Hidalgo, A.; Dellamora-Ortiz, G.; Mateo, C.; Fernandez-Lafuente, R.; Guisan, J.M. Stabilization of different alcohol oxidases via immobilization and post immobilization techniques. Enzyme Microb. Technol. 2007, 40, 278-284. [CrossRef]

83. Falus, P.; Cerioli, L.; Bajnoczi, G.; Boros, Z.; Weiser, D.; Nagy, J.; Tessaro, D.; Servi, S.; Poppe, L. A Continuous-Flow Cascade Reactor System for Subtilisin A-Catalyzed Dynamic Kinetic Resolution of N-tert-butyloxy-carbonylphenylalanine Ethyl Thioester with Benzylamine. Adv. Synth. Catal. 2016, 358, 1608-1617. [CrossRef]

84. Knezevic, Z.; Milosavic, N.; Bezbradica, D.; Jakovljevic, Z.; Prodanovic, R. Immobilization of lipase from Candida rugosa on Eupergit C supports by covalent attachment. Biochem. Eng. J. 2006, 30, 269-278. [CrossRef]

85. Bolivar, J.M.; Nidetzky, B. Positively Charged Mini-Protein $Z_{\text {basic2 }}$ as a Highly Efficient Silica Binding Module: Opportunities for Enzyme Immobilization on Unmodified Silica Supports. Langmuir 2012, 28, 10040-10049. [CrossRef] [PubMed]

86. Bolivar, J.M.; Nidetzky, B. Smart enzyme immobilization in microstructured reactors. Microreactors 2013, 31, 50-54.

87. Zhao, X.; Qi, F.; Yuan, C.; Du, W.; Liu, D. Lipase-catalyzed process for biodiesel production: Enzyme immobilization, process simulation and optimization. Renew. Sustain. Energy Rev. 2015, 44, 182-197. [CrossRef]

88. Mendes, A.A.; Freitas, L.; Carvalho, A.K.F.D.; Oliveira, P.C.D.; Castro, H.F.D. Immobilization of a Commercial Lipase from Penicillium camembertii (Lipase G) by Different Strategies. Enzyme Res. 2011. [CrossRef] [PubMed]

89. Petri, A.; Marconcini, P.; Salvadori, P. Efficient immobilization of epoxide hydrolase onto silica gel and use in the enantioselective hydrolysis of racemic para-nitrostyrene oxide. J. Mol. Catal. B Enzym. 2005, 32, 219-224. [CrossRef]

90. Alptekin, O.; Tukel, S.S.; Yildirim, D.; Alagoz, D. Immobilization of catalase onto Eupergit C and its characterization. J. Mol. Catal. B Enzym. 2010, 64, 177-183. [CrossRef]

91. Ferraz, L.I.R.; Possebom, G.; Alvez, E.V.; Cansian, R.L.; Paroul, N.; Oliveira, D.D.; Treichel, H. Application of home-made lipase in the production of geranyl propionate by esterification of geraniol and propionic acid in solvent-free system. Biocatal. Agric. Biotechnol. 2015, 4, 44-48. [CrossRef]

92. Risso, F.V.A.; Mazutti, M.A.; Treichel, H.; Costa, F.; Maugeri, F.; Rodrigues, M.I. Effect of Organic Solvent on the Characteristics of Free and Immobilized Inulinase from Kluyveromyces marxianus ATCC 16045. Food Technol. Biotechnol. 2010, 48, 143-150.

93. Arica, M.Y.; Oktem, H.A.; Oktem, Z.; Tuncel, S.A. Immobilization of catalase in poly(isopropylacrylamideco-hydroxythylmethacrylate) thermally reversible hydrogels. Polym. Int. 1999, 48, 879-884. [CrossRef]

94. Singh, H.P.; Gupta, N.; Sharma, R.K. Hollow Silica Nanoparticles as Support for Catalase Enzyme Immobilization. Catal. Lett. 2013, 143, 1304-1311. [CrossRef]

95. Yan, M.; Liu, Z.; Lu, D.; Liu, Z. Fabrication of Single Carbonic Anhydrase Nanogel against Denaturation and Aggregation at High Temperature. Biomacromolecules 2007, 8, 560-565. [CrossRef] [PubMed]

96. Prakasham, R.S.; Devi, G.S.; Rao, C.S.; Sivakumar, V.S.S.; Sathish, T.; Sarma, P.N. Nickel-Impregnated Silica Nanoparticle Synthesis and Their Evaluation for Biocatalyst Immobilization. Appl. Biochem. Biotechnol. 2010, 160, 1888-1895. [CrossRef] [PubMed] 
97. Wu, X.; Ge, J.; Yang, C.; Hou, M.; Liu, Z. Facile synthesis of multiple enzyme-containing metal-organic frameworks in a biomolecule friendly environment. Chem. Commun. 2015, 51, 13408-13411. [CrossRef] [PubMed]

98. Lin, Z.; Xiao, Y.; Wang, L.; Yin, Y.; Zheng, J.; Yang, H.; Chen, G. Facile synthesis of enzyme-inorganic hybrid nanoflowers and their application as an immobilized trypsin reactor for highly efficient protein digestion. RSC Adv. 2014, 4, 13888-13891. [CrossRef]

99. Cao, L.; Rantwijk, F.V.; Sheldon, R.A. Cross-Linked Enzyme Aggregates: A Simple and Effective Method for the Immobilization of Penicillin Acylase. Org. Lett. 2000, 2, 1361-1364. [CrossRef] [PubMed]

100. Sheldon, R.A. Cross-Linked Enzyme Aggregates as Industrial Biocatalysts. Org. Process Res. Dev. 2011, 15, 213-223. [CrossRef]

101. Illanes, A.; Wilson, L.; Altamirano, C.; Cabrera, Z.; Alvarez, L.; Aguirre, C. Production of cephalexin in organic medium at high substrate concentrations with CLEA of penicillin acylase and PGA-450. Enzyme Microb. Technol. 2007, 40, 195-203. [CrossRef]

102. Vafiadi, C.; Topakas, E.; Christakopoulos, P. Preparation of multipurpose cross-linked enzyme aggregates and their application to production of alkyl ferulates. J. Mol. Catal. B Enzym. 2008, 54, 35-41. [CrossRef]

103. Zhao, L.; Zheng, L.; Gao, G.; Jia, F.; Cao, S. Resolution of N-(2-ethyl-6-methyl-phenyl) alanine via cross-linked aggregates of Pseudomonas sp. Lipase. J. Mol. Catal. B Enzym. 2008, 54, 7-12. [CrossRef]

104. Martins, S.L.; Albuquerque, B.F.; Nunes, M.A.P.; Ribeiro, M.H.L. Exploring magnetic and imprinted cross-linked enzyme aggregates of rhamnopyranosidase in microbioreactors. Bioresour. Technol. 2018, 249, 704-712. [CrossRef] [PubMed]

105. Nguyen, L.T.; Yang, K.-L. Combined cross-linked enzyme aggregates of horseradish peroxidase and glucose oxidase for catalyzing cascade chemical reactions. Enzyme Microb. Technol. 2017, 100, 52-59. [CrossRef] [PubMed]

106. Lai, J.-Q.; Hu, Z.-L.; Sheldon, R.A.; Yang, Z. Catalytic performance of cross-linked enzyme aggregates of Penicillium expansum lipase and their use as a catalyst for biodiesel production. Process Biochem. 2012, 47, 2058-2063. [CrossRef]

107. Nuijens, T.; Cusan, C.; Schepers, A.C.H.M.; Kruijtzer, J.A.W.; Rijkers, D.T.S.; Liskamp, R.M.J.; Quaedflieg, P.J.L.M. Enzymatic synthesis of activated esters and their subsequent use in enzyme-based peptide synthesis. J. Mol. Catal. B Enzym. 2011, 71, 79-84. [CrossRef]

108. Cui, J.-D.; Zhang, S.; Sun, L.-M. Cross-Linked Enzyme Aggregates of Phenylalanine Ammonia Lyase: Novel Biocatalysts for Synthesis of L-Phenylalanine. Appl. Biochem. Biotechnol. 2012, 167, 835-844. [CrossRef] [PubMed]

109. Taboada-Puig, R.; Junghanns, C.; Demarche, P.; Moreira, M.T.; Feijoo, G.; Lema, J.M.; Agathos, S.N. Combined cross-linked enzyme aggregates from versatile peroxidase and glucose oxidase: Production, partial characterization and application for the elimination of endocrine disruptors. Bioresour. Technol. 2011, 102, 6593-6599. [CrossRef] [PubMed]

110. Thirkettle, J. SB-253514 and Analogues; Novel Inhibitors of Lipoprotein Associated Phospholipase $\mathrm{A}_{2}$ Produced by Pseudomonas fluorescens DSM 11579. J. Antibiot. 2000, 53, 733-735. [CrossRef] [PubMed]

111. O'Connell, P.J.; Harms, C.T.; Allen, J.R.F. Metolachlor, S-metolachlor and their role within sustainable weed management. Crop Prot. 1998, 17, 207-212. [CrossRef]

112. Dinu, C.Z.; Borkar, I.V.; Bale, S.S.; Campbell, A.S.; Kane, R.S.; Dordick, J.S. Perhydrolase-nanotube-paint sporicidal composites stabilized by intramolecular crosslinking. J. Mol. Catal. B Enzym. 2012, 75, $20-26$. [CrossRef]

113. Ren, T.; Mao, Z.; Moya, S.E.; Gao, C. Immobilization of Enzymes on 2-Hydroxyethylm Methacrylate and Glycidyl Methacrylate Copolymer Brushes. Chem. Asian. J. 2014, 9, 2132-2139. [CrossRef] [PubMed]

114. Fuentes, M.; Segura, R.L.; Abian, O.; Betancor, L.; Hidalgo, A.; Mateo, C.; Fernandez-Lafuente, R.; Guisan, J.M. Determination of protein-protein interactions through aldehyde-dextran intermolecular cross-linking. Proteomics 2004, 4, 2602-2607. [CrossRef] [PubMed]

115. Liese, A.; Hilterhaus, L. Evaluation of immobilized enzymes for industrial applications. Chem. Soc. Rev. 2013, 42, 6236-6249. [CrossRef] [PubMed]

116. Dach, R.; Song, J.J.; Roschangar, F.; Samstag, W.; Senanayake, C.H. The Eight Criteria Defining a Good Chemical Manufacturing Process. Org. Process Res. Dev. 2012, 16, 1697-1706. [CrossRef] 
117. Zhou, H.; Qu, Y.; Chunlei; Kong; Li, D.; Shen, E.; Ma, Q.; Zhang, X.; Wang, J.; Zhou, J. Catalytic performance and molecular dynamic simulation of immobilized C-C bond hydrolase based on carbon nanotube matrix. Colloids Surfaces B Biointerfaces 2014, 116, 365-371. [CrossRef] [PubMed]

118. Basso, A.; Spizzo, P.; Ferrario, V.; Knapic, L.; Savko, N.; Braiuca, P.; Ebert, C.; Ricca, E.; Calabro, V.; Gardossi, L. Endo- and Exo-Inulinases: Enzyme-Substrate Interaction and Rational Immobilization. Biotechnol. Prog. 2010, 26, 397-405. [CrossRef] [PubMed]

119. Franca, E.F.; Leite, F.L.; Cunha, R.A.; Oliveira, O.N., Jr.; Freitas, L.C.G. Designing and enzyme-based nanobiosensor using molecular modeling techniques. Phys. Chem. Chem. Phys. 2011, 13, 8894-8899. [CrossRef] [PubMed]

120. Mathpati, A.C.; Vyas, V.K.; Bhanage, B.M. Kinetic resolution of 1,2-diols using immobilized Burkholderia cepacia lipase: A combined experimental and molecular dynamics investigation. J. Biotechnol. 2017, 262, 1-10. [CrossRef] [PubMed]

121. Allen, M.P.; Teldesley, D.J. Computer Simulations of Liquids; Oxford University Press: New York, NY, USA, 1987.

122. Maarel, M.J.E.C.V.D.; Veen, B.V.D.; Uitdehaag, J.C.M.; Leemhuis, H.; Dijkhuizen, L. Properties and applications of starch-converting enzymes of the alpha-amylase family. J. Biotechnol. 2002, 94, 137-155. [CrossRef]

123. Rasor, J.P.; Voss, E. Enzyme-catalyzed processes in pharmaceutical industry. Appl. Catal. A Gen. 2001, 221, 145-158. [CrossRef]

124. Petroleum, British. BP Statistical Review of World Energy; Petroleum, British: London, UK, 2017.

125. Qiu, C.; Colson, G.; Escalante, C.; Wetzstein, M. Considering macroeconomic indicators in the food before fuel nexus. Energy Econ. 2012, 34, 2021-2028. [CrossRef]

126. Rabideau, B.D.; Ismail, A.E. Mechanisms of hydrogen bond formation between ionic liquids and cellulose and the influence of water content. Phys. Chem. Chem. Phys. 2015, 17, 5767-5775. [CrossRef] [PubMed]

127. Viell, J.; Inouye, H.; Szekely, N.K.; Frielinghaus, H.; Marks, C.; Wang, Y.; Anders, N.; Spiess, A.C.; Makowski, L. Multi-scale processes of beech wood disintegration and pretreatment with 1-ethyl-3-methylimidazolium acetate/water mixtures. Biotechnol. Biofuels 2016, 9, 7. [CrossRef] [PubMed]

128. Pinkert, A.; Marsh, K.N.; Pang, S.; Staiger, M.P. Ionic Liquids and Their Interaction with Cellulose. Chem. Rev. 2009, 109, 6712-6728. [CrossRef] [PubMed]

129. Blanchette, C.D.; Knipe, J.M.; Stolaroff, J.K.; DeOtte, J.R.; Oakdale, J.S.; Maiti, A.; Lenhardt, J.; Sirajuddin, S.; Rosenzweig, A.C.; Baker, S.E. Printable enzyme-embedded materials for methane to methanol conversion. Nat. Commun. 2016, 7, 11900. [CrossRef] [PubMed]

130. Stone, K.A.; Hilliard, M.V.; He, Q.P.; Wang, J. A mini review on bioreactor configurations and gas transfer enhancements for biochemical methane conversion. Biochem. Eng. J. 2017, 128, 83-92. [CrossRef]

131. Strong, P.J.; Xie, S.; Clarke, W.P. Methane as a Resource: Can the Methanotrophs Add Value? Environ. Sci. Technol. 2015, 49, 4001-4018. [CrossRef] [PubMed]

132. Agyei, D.; Danquah, M.K. Industrial-scale manufacturing of pharmaceutical-grade bioactive peptides. Biotechnol. Adv. 2011, 2011, 272-277. [CrossRef] [PubMed]

133. Fernandez-Lucas, J.; Castaneda, D.; Hormigo, D. New trends for a classical enzyme: Papain, a biotechnological success story in the food industry. Trends Food Sci. Technol. 2017, 68, 91-101. [CrossRef]

134. Lima-Ramos, J.; Tufvesson, P.; Woodley, J.M. Application of environmental and economic metrics to guide the development of biocatalytic processes. Green Process. Synth. 2014, 3, 195-213. [CrossRef]

135. Tufvesson, P.; Lima-Ramos, J.; Haque, N.A.; Gernaey, K.V.; Woodly, J.M. Advances in the Process Development of Biocatalytic Processes. Org. Process Res. Dev. 2013, 17, 1233-1238. [CrossRef]

136. Sheldon, R.A.; Woodley, J.M. Role of Biocatalysis in Sustainable Chemistry. Chem. Rev. 2018, 118, 801-838. [CrossRef] [PubMed]

(C) 2018 by the authors. Licensee MDPI, Basel, Switzerland. This article is an open access article distributed under the terms and conditions of the Creative Commons Attribution (CC BY) license (http:/ / creativecommons.org/licenses/by/4.0/). 